\title{
Spatial Spillover Effect and Action Path of Electricity Consumption Driven by China's Financial Development based on Global Co-integration
}

Jianjun Xu

Ningbo University

Xuejiao Ma ( $\triangle$ maxuejiao@dlut.edu.cn )

Dalian University of Technology https://orcid.org/0000-0003-0445-0976

Xiaoqing Xu

Dongbei University of Finance and Economics

\section{Research Article}

Keywords: Electricity consumption, Financial development, Global spatial panel co-integration, Spatial spillover, Mediation effect

Posted Date: November 2nd, 2021

DOI: https://doi.org/10.21203/rs.3.rs-958197/v1

License: (c) (i) This work is licensed under a Creative Commons Attribution 4.0 International License. Read Full License

Version of Record: A version of this preprint was published at Environmental Science and Pollution Research on March 12th, 2022. See the published version at https://doi.org/10.1007/s11356-022-193866. 
2 Spatial Spillover Effect and Action Path of Electricity Consumption Driven 3 by China's Financial Development based on Global Co-integration

${ }^{a}$ College of Science and Technology, Ningbo University, Ningbo, China, email: xu-jj@ hotmail.com

b,* School of Economics and Management, Dalian University of Technology, Dalian, China, *email: maxuejiao@dlut.edu.cn, +186244338689

c School of Statistics, Dongbei University of Finance and Economics, Dalian, China, *email: sdrsxxq1996@163.com

Abstract: Although studies on the influencing factors of electricity consumption are rich, the focus on the relationship between financial development and electricity consumption is scarce due to the characteristics of financial sector. In fact, the financial development cannot only increase electricity consumption, but also have the spatial spillover effects. Based on the global spatial modelling techniques, the long-term and short-term relationship between financial development and electricity consumption is examined, and the intermediary effect of financial development on electricity consumption through economic growth, urbanization and industrial structure optimization is also verified. Results show that there is a global co-integration relationship between financial development, economic growth, urbanization, industrial structure optimization and China's electricity consumption, rather than a local co-integration relationship. When the short-term change of electricity consumption deviates from the equilibrium state, the global error correction mechanism can promote the unbalanced system to return to equilibrium from time and spatial dimension. This study not only confirms the spatial spillover effects, but also heterogeneous influences of financial development on electricity consumption, which provides new evidence to make relevant policies.

Keywords: Electricity consumption; Financial development; Global spatial panel co-integration; Spatial

\section{Introduction}

Electric energy, as a representative of modern energy, can reflect the economic development level of a country (Niu et al., 2013). Although income per capita of China has just reached the middle-income level, the degree of electrification in various sectors has been relatively high since 2010. As shown in Fig. 1, both total and average electricity consumption of China present a sharp rise from 1978 to 2019, especially after 2000. Thus, a correct understanding of the driving force for the rapid growth of China's electricity consumption cannot only provide important empirical evidence for the corresponding policy adjustments, but also have important significance for easing the contradiction between China's electricity supply and demand. 


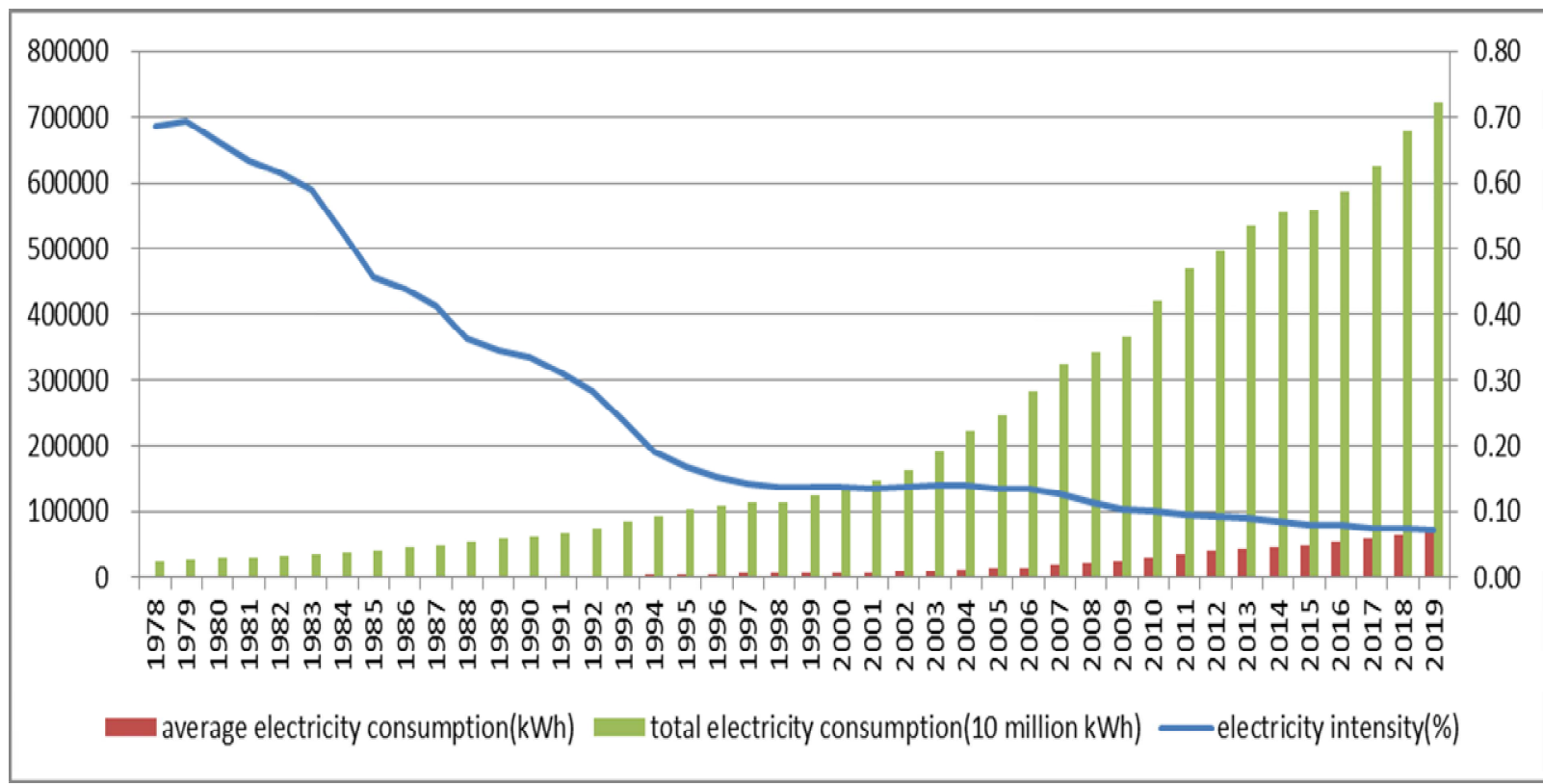

Figure 1 Electricity consumption in China during 1978-2019

A variety of factors can influence the electricity consumption, such as population, economic development, urbanization, industrial structure, technological progress and foreign direct investment. Existing studies have conducted many tentative discussions on those factors (Lean and Smyth, 2014; Shahbaz et al., 2014; Acaravci et al., 2015; Lin et al., 2016; Wang et al, 2018; Ohlan, 2018; Khan et al., 2018; Yin et al., 2018; Liu et al., 2020; An et al., 2020; Ma, 2020; Yuan and Zhao, 2021), but most of them ignore the impact of financial factors (Mahalik et al. 2017). In fact, finance is the core of modern economy, which has an important influence on the production and consumption of energy as the material basis in the process of social and economic development. For one thing, developed financial institutions and capital markets can provide debt and equity financing for energy sectors, especially for green renewable energy projects to promote the production and sales of electricity energy (Dasgupta et al., 2004; Chang, 2015). For another, the growth of financial intermediary is able to offer credit support to consumers so that they can purchase the electricity-energy-consuming machinery and equipment such as cars, houses, refrigerators, air conditioners, and washing machines (Sadorsky, 2011). Additionally, the stock market activity can be regarded as a leading and prosperous economic indicator (Mankiw and Scarth, 2008), which in turn stimulates the consumption and energy demands.

Specifically, a sound financial service system will have multiple impacts on electricity energy consumption through three channels: 1) Economic growth. Financial development plays a pivotal role in promote the economic growth, such as mobilization of savings, information disclosure, corporate governance, risk dispersion, and facilitating transactions (Levine, 1997; Christopoulos et al., 2004; Levine, 2005; Hassan et al., 2011; Rana and Barua, 2015; Asteriou and Spanos, 2019). Further, the economic growth needs an enormous demand for electricity consumption (Payne, 2010; Ouédraogo, 2010; Yoo and Kwak, 2010; Shahbaz et al., 2011; Hamdi, 2014; Sbia et al., 2017; Wang et al., 2018; Zhong et al., 2019; Apergis and Payne, 2012; Wolde-Rufael, 2014; Osman et al., 2016; Usman et al., 2020); 2) Urbanization development. A sound financial development environment indicates the expansion of financial scale, optimization of financial structure and improvement of financial 
efficiency, which will be conducive to promote the financing of small and medium enterprises and optimize the asset allocation between urban and rural. Thus, the financial development can affect the urbanization level, and in turn, the rapid process of urbanization can increase the electricity consumption (Sadorsky, 2013); 3) Industrial structure. The financial development means that the industrial structure has been optimized and transformed from the secondary to the tertiary industry, and sufficient financial support can be provided for the upgrading of the industrial structure (Bencivenga and Smith, 1991; King and Levine, 1993). The optimization of industrial structure contributes to the reduction of energy-intensive industries and total electricity consumption.

Due to different influencing mechanism, empirical results of whether financial development promotes or hinders electricity consumption are inconsistent. Some studies proved the positive impact (Sadorsky, 2010; Sadorsky, 2011; Çoban and Topcu, 2013; Islam et al., 2013; Mahalik et al., 2017; Danish, 2018; Nguyen et al., 2021); while other scholars obtained the opposite conclusions (Islam et al. 2013; Kahouli 2017; Farhani and Solarin 2017). There are also some studies confirming that the impact of different financial indicators has heterogeneity (Chang, 2015). Although some literature has attempted to analyze their relations by applying various methods, including linear dynamic panel model (Sadorsky, 2010), auto-regressive distribution lag (ARDL) boundary (Shahbaz et al., 2011) and Granger causality (Islam et al., 2013), most of studies fail to consider the cross-section dependence and spatial correlation between variables at the same time. In fact, many macroeconomic variables, such as financial development indicators, GDP (Sharif et al., 2019), housing price, population, and wage rate (Kosfeld and Dreger, 2018; 2019) have been proven to have both cross-section dependence and non-stationary characteristics, which should be analyzed by non-stationary spatial modeling technique proposed by Beenstock and Felsenstein $(2010 ; 2015 ; 2019)$. Due to its late emergence, its practical application is still limited though it is effective in analyzing some typical problems. Based on the above research gaps, in this paper, by using the non-stationary spatial modeling approach, we are interested in exploring the longand short-term local impact of financial development on electricity consumption of China and the spatial spillover impact of neighboring areas under static and dynamic time-spatial conditions as well as revealing the specific influencing mechanism of economic growth, urbanization and industrial structure.

Main contributions of this paper are fourfold: First, the modern spatial panel modeling technique integrated with the non-stationary panel co-integration analysis method is employed to analyze the internal relationship between financial development and electricity consumption of China, which can reveal the spatial spillover effects. By considering the cross-section dependence and non-stationarity of variables, our work extends the application range of panel data with both non-independent and non-stationary characteristics. Second, we focus on revealing the global co-integration relationship between variables rather than only a local co-integration relationship in time dimension. When the short-term change of electricity consumption deviates from the equilibrium state, the role of global error correction mechanism will lead the system to the equilibrium state from the time and spatial dimensions simultaneously, which is the first attempt to draw that conclusion. Third, from the long-term and short-term perspectives, this paper not only confirms the existence of "local effect" (direct impact) of the impact of financial development on electricity consumption of China, but also proves the existence of "neighboring effect" (spatial spillover). Finally, the mediating effect analysis is applied to investigate the influencing 
mechanism between financial development and electricity consumption. Additionally, we also discuss the heterogeneity of financial scale, structure and efficiency on the electricity consumption.

The rest of this paper is arranged as follows: Section 2 is literature review, and methodology are included in Section 3. Section 4 is data and variables, and empirical results are presented in Section 5. Section 6 gives conclusions and policy implications.

\section{Literature Review}

Many studies have attempted to analyze how financial development can directly affect electricity consumption. Lin et al. (2016), based on the data during 1980-2011, used Johansen co-integration and vector error correction model to study influencing factors on renewable electricity consumption of China, and results show that the financial development could promote the renewable electricity consumption, and there was a one-way short-term causal relationship between them. Rafindadi and Ozturk (2016) applied the ARDL and VECM Granger causality test to examine the long- and short-term effects of financial development on the electricity energy dilemma in Japan, and empirical results suggested that a $1 \%$ increase in financial development would separately lead to a $0.2429 \%$ and $0.2210 \%$ increase in Japan's electricity consumption in the long and short run. Sbia et al. (2017) selected the United Arab Emirates as the research objective and analyzed the long-term impact of financial development on electricity consumption under the condition of structural mutation by using the ARDL boundary test method. Empirical results verified the promoting effect of electricity consumption. Faisal et al. (2018) analyzed the relationship between financial development and electricity consumption by using the quarterly data of Turkey. Based on the joint co-integration test and ARDL test, results indicated the existence of an inverted $U$-shaped relationship between them in the both long and short term. By employing the co-integration method of structural fracture, Solarin et al. (2019) studied the impact of financial development on electricity consumption of Malaysia from 1990 to 2015, and results provided evidence for a positive correlation between the two variables and the existence of a two-way causality.

\section{2 impact of financial development on electricity consumption through meditation effect}

Financial development can affect electricity consumption through multiple paths. This study focuses on the intermediary effect of economic growth, urbanization and industrial structure optimization on electricity consumption.

\subsubsection{Relationship between economic growth and electricity consumption}

The impact of economic growth on electricity consumption has been proved by a large number of literature. Payne (2010) summarized various hypotheses related to causality between electricity consumption and economic growth before 2009. The results showed that $18.03 \%$ of countries supported the hypothesis that economic growth promotes electricity consumption. Ouédraogo (2010) empirically tested the causal relationship between electricity consumption and economic growth in Burkina Faso from 1968 to 2003. The results showed that there was a two-way causal relationship between electricity consumption and real GDP. Yoo and Kwak (2010) used time series modeling technology to study the causal relationship between electricity consumption and economic growth in seven South American countries in 1975-2006. The results proved that only in Venezuela, the increase of electricity consumption directly affected economic growth, and economic growth also stimulated the further 
electricity consumption of the country. Shahbaz et al. (2011) re-examined the relationship among electricity consumption, economic growth and employment in Portugal based on the sample period data from 1971 to 2009 using the framework of co-integration and Granger causality. The results revealed that the electricity consumption, economic growth and employment in Portugal were co-integrated, and there was a one-way Granger causality between economic growth and electricity consumption. Hamdi et al. (2014) took the kingdom of Bahrain as an example and applied the ARDL test method to demonstrate the co-integration relationship among electricity consumption, foreign direct investment, capital and economic growth. VECM Granger causality analysis revealed the feedback effect between electricity consumption and economic growth. Wang et al. (2018) proposed a new bootstrap Granger causality test method, which used quarterly data sets containing more dynamic changes to re-investigate the relationship between electricity consumption and economic growth. They concluded that there was a strong one-way Granger causality between GDP and electricity consumption. Zhong et al (2019) used ARDL bound test method to explore the relationship between electricity consumption, economic growth and employment in China during 1971-2009. The long-term equilibrium co-integration among the three co-variates was determined. In the framework of panel error correction model, Apergis and Payne (2012) took Central America as an example to realize the long-term equilibrium relationship between real GDP, renewable electricity consumption, non renewable electricity consumption, real gross fixed capital formation and labor force. In the short-term and long-term, there was a two-way causal relationship between non renewable electricity consumption and economic growth. Wolde-Rufael (2014) re-examined the Granger causality between electricity consumption and economic growth of 15 transition economies in 1975-2010 using the bootstrap panel causality method, and found that Ukraine had two-way causality, while the Czech Republic, Latvia, Lithuania and the Russian Federation only had one-way causality from economic growth to electricity consumption. Osman et al. (2016) analyzed the relationship between electricity consumption and economic growth using panel data of the annual GCC countries from 1975 to 2012. The results showed that there was a long-term equilibrium and two-way causality between electricity consumption and economic growth, which supported the feedback hypothesis.

\subsubsection{Relationship between urbanization development and electricity consumption}

With the annual time series data of Nigeria from 1985 to 2005, Ubani (2013) used multiple linear regression test to study the relationship between urbanization, population density, number of manufacturing industry, number of households using electricity, employment rate, and electricity consumption, and they concluded that electricity consumption was significantly related to six of the 12 socio-economic and physical factors, which were of great significance in determining electricity consumption in Nigeria. Based on the ARDL boundary test, and supplemented by the Gregory Hansen structural fracture co-integration process, Solarin and Shahbaz (2013) confirmed the long-term relationship between economic growth, urbanization and electricity consumption by using the data of Angola from 1971 to 2009, VECM-Granger causality test observed that the interaction between urbanization and electricity consumption. Dong and Hao (2018) made a quantitative analysis of the relationship between urbanization, urban-rural income gap and per capita electricity consumption by using China's provincial panel data from 1996 to 2013, confirming that the improvement of urbanization and industrialization level, the 
consumption. Liu et al (2020) combined with panel data of 30 provinces in China from 2005 to 2017 and studied the nonlinear dynamic threshold effect of China's urbanization on electricity consumption by using the dynamic threshold model. The results showed that when the threshold variable value exceeds the threshold value, the promotion effect of population urbanization rate on per capita electricity consumption and per capita industrial electricity consumption would be significantly weakened; However, the promotion effect of population urbanization rate on per capita electricity consumption would be significantly enhanced. The impact of population urbanization rate on per capita electricity consumption or per capita industrial electricity consumption in the eastern region was weaker than that in the central and western regions, while the impact of population urbanization rate on per capita industrial electricity consumption in the eastern region was stronger than that in the central and western regions.

\subsubsection{Relationship between industrial structure optimization and electricity consumption}

Al-Bajjali and Shamayleh (2018) combined with the annual data from 1986 to 2015 and used Johansen co integration to test the determinants of Jordan's electricity consumption. It showed that there was a long-term relationship between GDP, economic structure, electricity price, population, urbanization, total water consumption and electricity consumption. The regression results of VECM showed that GDP, urbanization, economic structure and total water consumption were positively correlated with electricity consumption. Cheng et al. (2018) used the dynamic spatial panel model to analyze the impact of industrial structure and technological progress on carbon intensity, to explore the factors that may lead to the decline of carbon intensity in China. Empirical results indicated that although the upgrading and optimization of industrial structure was conducive to reducing the intensity of carbon emissions, and technological progress played the most important role in China. The change of efficiency was the main factor to reduce carbon intensity. Although technological change itself could not directly reduce the intensity of carbon emissions, it could indirectly reduce the intensity of carbon emissions by promoting the upgrading and optimization of industrial structure. Based on the provincial data of China from 1999 to 2017, An et al. (2020) constructed a spatial panel model to test the inhibition of technological progress and industrial structure optimization on China's electricity consumption, and found that the electricity consumption among provinces in China was positively spatial related and had certain "path dependence" characteristics. Technological progress and industrial structure upgrading had a stabilizing effect on the electricity consumption of the whole country. There were also large differences between the eastern, central and western regions, as well as between the southern China power grid and the service areas of the national home appliance network.

\subsection{Research gaps}

The existing literature have used different econometric analysis methods to demonstrate the impact of financial development, economic growth, urbanization, industrial structure optimization on the electricity consumption of a country or region, and drew some very enlightening conclusions. However, it is regrettable that the existing empirical literature on the relationship between financial development, economic growth, urbanization, industrial structure optimization and electricity consumption does not consider the dual characteristics of non-stationary and cross-sectional dependence of these variables, which will affect the reliability of the estimated results. Therefore, this study constructs a global spatial panel co-integration and spatial panel 
error correction model to empirically analyze and compare the "local effect" and "neighboring effect" impact of China's financial development on electricity consumption. Further, economic growth, urbanization and industrial structure optimization are used as mediating variables to deeply explore the internal correlation mechanism among 214 them.

\section{3. Methodology and variables}

\section{$216 \quad 3.1$ Global co-integration analysis}

The global co-integration analysis is applied to judge whether the selected panel data is independent or stationary. Only when the data satisfy the cross-section dependence and non-stationarity, can the global co-integration relationship be identified and space error correction model be used. Schematic diagram of global co-integration is shown in Fig. 2.

Fig. 2. Schematic diagram of global co-integration modeling idea

\subsubsection{Cross-section dependence test}

In this paper, to obtain robust results, the Lagrange multiplier (LM1) (Breusch and Pagan, 1980), the modified LM 1 (LM2) (Pesaran, 2004), the LM Test (LM3) (Baltgi et al., 2012) and the cross-section dependence test (CD) (Pesaran (2004) are applied in identifying the cross-section dependence. The test statistics of LM methods are constructed based on the square of correlation coefficient of the regression residual; while the CD test is only based on the correlation coefficient of the regression residual. Their equations are as follows:

$$
\begin{gathered}
L M_{1}=T \sum_{i=1} \sum_{j=i+1} \rho_{i j}^{2} \\
L M_{2}=\sqrt{\frac{1}{N(N-1)}} \sum_{i=1}^{N-1} \sum_{j=i+1}^{N}\left(T \rho_{i j}^{2}-1\right) \\
L M_{3}=L M_{2}-\frac{N}{2(T-1)} \\
C D=\sqrt{\frac{2 T}{N(N-1)}}\left|\sum_{i=1}^{N-1} \sum_{j=i+1}^{N} \rho_{i j}\right|
\end{gathered}
$$

Where $\rho_{i j}$ is a pairwise correlation coefficient based on OLS regression residuals; $N$ represents panels and $T$ represents time series. The null hypothesis $H_{0}$ of them is that the cross-section units are independent of each other, and if it is rejected, the cross-section of the sample is dependent.

\subsubsection{Stationary test}

The second issue to be addressed is to judge whether the panel data is stationary by applying the panel unit root test that can be divided into two generations according to different assumptions of the correlation of section elements. The first generation of panel unit root test assumes that the cross-section elements are independent of 
each other, such as LLV test (Levin et al., 2002) and IPS test (Im et al., 2003). Although those methods have been widely used in the analysis of cross-sectional panel data, results of the test may not be robust due to the existence of spatially dependent variables. Further, the second generation of panel unit root tests fully considers the cross-section dependence by taking into account all the random and common factors faced by each cross-section element, making the stationarity test of variables more effective, such as MP test (Moon and Perron, 2004) and CIPS test (Pesaran, 2007). This paper applies the IPS test of the first generation and CIPS test of the second generation to conduct the stationary test.

Based on $\boldsymbol{E q}$. (5), the IPS test is to carry out OLS regression for each cross-section unit, and then get the $t_{i}$ statistics corresponding to the estimated $\hat{b}_{i}$ of each cross-section unit, which is recorded as $t_{i T}\left(p_{i}\right)$. After that, the mean value of $t_{i}$ statistics is used to construct the extended dicker fuller Statistics (ADF) to test whether there is a unit root in panel data $y$. The IPS statistics can be calculated by $\boldsymbol{E q}$. (6). The null hypothesis of IPS test is $H_{0}: b_{i}=0, i=1,2, \ldots N$; while the alternative hypothesis is $H_{1}: b_{i}=0, i=1,2, \ldots N_{1}$; . $b_{i}<0, i=N_{1}+1, N_{1}+2, \ldots N$.

\subsubsection{Co-integration test}

After examining the cross-section dependence and the panel unit root, the spatial Durbin model (SDM) is constructed to further test whether there is a global co-integration relationship between variables.

$$
Y_{i t}=\alpha_{1}+\beta_{1} X_{i t}+\sum_{i=1}^{n} \gamma_{i}^{a} C t r_{i t}+\delta_{1} W Y_{i t}+\beta_{2} W X_{i t}+\sum_{i=1}^{n} \gamma_{i}^{b} W C t r_{i t}+\mu_{i t}
$$

Where $W$ is the spatial weight matrix, $W \Delta(\cdot)_{i t}=\sum_{j \neq i}^{N} W_{i j} \Delta(\cdot)_{j t} ; \mu_{i t}$ is the residual term.

Referring to the definition of Beenstock and Felsenstein (2019), the global co-integration relationship between independent and dependent variables can be judged according to the significance of estimated parameters of $\boldsymbol{E q}$. (9). If $\beta_{1}$ and $\gamma_{i}^{a}$ are not all zeros, $\delta_{1}=\beta_{2}=\gamma_{i}^{b}(i=1,2, \ldots n)=0$, and $\mu_{i t}$ is stationary, there is a local co-integration relationship between independent and dependent variables, which means that the co-integration relationship among those variables occurs in the spatial unit rather than between spatial units. So the long-term trend between variables is only affected by the interaction of factors in the spatial unit instead of the relative change of factors in the spatial unit; if $\beta_{1}=\gamma_{i}^{\mathrm{a}}=0, \delta_{1}, \beta_{2}, \gamma_{i}^{\mathrm{b}}(i=1,2, \ldots n)$ are not all zeros, and $\mu_{i t}$ is stationary, the spatial co-integration relations among these variables exist, which implies that the co-integration relations 
occur between spatial units instead of within spatial units. Then the long-term trend among variables is affected by the factors among spatial units, but has nothing to do with the changes of factors within spatial units. If $\beta_{1}$ and $\gamma_{i}^{a}$ are not all zeros, $\delta_{1}, \beta_{2}, \gamma_{i}^{\mathrm{b}}(i=1,2, \ldots n)$ are not all zeros, and $\mu_{i t}$ is stationary, there is a global co-integration relationship among those variables, implying that the co-integration relationship among those variables occurs not only in spatial units but also between spatial units. The long-term trend is affected by the factors in and between spatial units. Under the premise of global co-integration, $\beta_{1}$ and $\gamma_{i}^{a}$ measure the direct effect of explaining variables on $Y$ in the long run; while $\beta_{2}$ and $\gamma_{i}^{b}$ measure the spatial spillover effect of explaining variables on $Y$ in the long run.

\subsection{Specification of spatial modelling technique}

The traditional error correction model (ECM) only reflects the error correction mechanism of the system itself in time domain. For the variables with global co-integration relationship, a spatial panel error model (SPECM) is constructed to further test whether there is an error correction mechanism from two dimensions of space and time.

$$
\begin{aligned}
\Delta \text { Elec }_{i t}= & \alpha_{2}+\delta_{2} \Delta \text { Elec }_{i t-1}+\beta_{3} \Delta F d_{i t-1}+\sum_{i=1}^{n} \gamma_{i}^{\mathrm{c}} \Delta \text { Ctr }_{i t-1}+\xi_{1} \mu_{i t-1} \\
& +\delta_{3} W \Delta \text { Elec }_{i t-1}+\beta_{4} W \Delta F d_{i t-1}+\sum_{i=1}^{n} \gamma_{i}^{\mathrm{d}} W \Delta C t r_{i t-1}+\xi_{2} W \mu_{i t-1}+v_{i t}
\end{aligned}
$$

Where $\Delta$ represents the difference of the variable; $W \Delta \operatorname{Ln}(\cdot)_{i t}=\sum_{j \neq i}^{N} W_{i j} \Delta \operatorname{Ln}(\cdot)_{j t} ; \operatorname{Elec}_{i t}$ is electricity consumption; $F d_{i t}$ is the financial development; $C t r_{i t}$ are control variables; $v_{i t}$ is the residual term. It is assumed that there is no sequence correlation in the period, but it may be spatially correlated, $\operatorname{cov}\left(v_{i t}, v_{j t}\right) \neq 0 ; W$ is the weight matrix; $\xi_{1}$ is the traditional local error correction coefficient, depicting the error correction mechanism in time domain; $\xi_{2}$ denotes the space error correction coefficient. When $\xi_{1}$ and $\xi_{2}$ are significant at the same time, the global error correction mechanism works. $\delta_{2}$ represents the influence of the previous period on $Y$ in the short term, measuring the inertial effect of $Y . \beta_{3}$ and $\gamma_{i}^{\mathrm{c}}$ measure the direct effect of explaining variables on $Y$ in the short term, and $\beta_{4}$ and $\gamma_{i}^{d}$ measure their spatial spillover effect.

\subsection{Mediating effect analysis}

To explore the influencing mechanism of financial development on electricity consumption, the mediating effect analysis is employed. Based on the ideas of Baron and Kenny (1986), Hayes (2013), the mediating effect model is established as follows:

$$
\begin{gathered}
\text { Elec }_{i t}=\psi_{0}+\psi_{1} F d_{i t}+\sum_{i=1}^{n} \eta_{i} C_{t r}+\mu_{i t} \\
\operatorname{Med}_{i t}=\phi_{0}+\phi_{1} X_{i t}+\sum_{i=1}^{n} \eta_{i} C t r_{i t}+\mu_{i t} \\
\operatorname{Elec}_{i t}=\varphi_{0}+\varphi_{1} F D_{i t}+\varphi_{2} \operatorname{Med}_{i t}+\sum_{i=1}^{n} \eta_{\mathrm{i}} C t r_{i t}+\mu_{i t}
\end{gathered}
$$

Substituting $\boldsymbol{E} \boldsymbol{q}$. (12) into $\boldsymbol{E q}$. (13), we can obtain:

$$
\operatorname{Elec}_{i t}=\left(\varphi_{0}+\phi_{0} \varphi_{2}\right)+\left(\varphi_{1}+\phi_{1} \varphi_{2}\right) F d_{i t}+\left(\varphi_{2} \sum_{i=1}^{n} \eta_{\mathrm{i}}+\sum_{i=1}^{n} \eta_{\mathrm{i}}\right) C t r_{i t}+\mu_{i t}
$$

From Eq. (14), $\phi_{1}=\varphi_{1}+\phi_{1} \varphi_{2}$ is the total influencing effect of financial development on electricity consumption, and $\phi_{1} \varphi_{2}$ measures the mediating effect through the mediating variables $\operatorname{Med}_{i t}$. in this paper, there are three mediating variables, which are economic growth, urbanization and industrial structure.

Specific steps of the mediating effect analysis are as follows: Step 1. Test the significance of the coefficient $\psi_{1}$. If it is significant, conduct Step 2; otherwise, stop the mediating effect and conclude that $F d$ is not correlated 
315 to Elec. Step 2. Test the significance of $\phi_{1}$ and $\varphi_{2}$ in $\boldsymbol{E q}$. (12) and (13). If both of them are significant, there is 316 indirect effect, and conduct Step 4. Or conduct Step 3 to test the stability. If at least one of them is not significant, 317 conduct Step 3. Step 3. Conduct Sobel test or bootstrap method to directly test the significance of indirect effect. If 318 it is significant and not zero, conduct Step 4, or stop the analysis. Step 4. Test the significance of $\varphi_{1}$ in $\boldsymbol{E} \boldsymbol{q}$. (13). If 319 it is not significant, it means the existence of full mediating effect, otherwise, the direct effect exists. Step 5. 320 Compare the sign of $\phi_{1} \varphi_{2}$ and $\varphi_{1}$, if they have the same sign, it belongs to the partial mediation effect, and report 321 the proportion of $\left(\phi_{1} \varphi_{2} / \psi_{1}\right)$; if the sign is different, it belongs to the masking effect, and report the absolute 322 proportion of $\left(\phi_{1} \varphi_{2} / \varphi_{1}\right)$.

\section{Variables and data}

\section{$324 \quad 4.1$ Variables}

The explained variable is electricity consumption, and according to the existing literature, it can be measured separately by total electricity consumption and per capita electricity consumption. This study is mainly considered from the overall perspective, so it is measured by total electricity consumption index, expressed by Toele.

The explaining variable is financial development, and its measurement methods can be divided into two categories. One is to construct corresponding measurement from different aspects of financial development connotation. For example, Chang (2015) constructed financial development indicators from five aspects: private credit, domestic credit, stock trading volume, stock market turnover rate and foreign direct investment to measure the financial development level of 53 countries; Yue et al. (2019) measured the financial development of 21 countries in transition from five aspects: financial intermediary scale, financial intermediary efficiency, stock market scale, stock market efficiency, and financial market openness. The other category is to use the principal component analysis to build a comprehensive measurement index. For example, Topcu and Payne (2017) combined the banking sector, stock market and bond market into a comprehensive index to measure the overall financial development, and used the index to analyze the connection between finance and energy consumption; Faisal et al. (2018) extracted the main components from four indicators, namely, broad money supply, domestic bank credit supply, domestic bank loans to the private sector and the proportion of private sector credit to GDP, and used the main components as the measurement indicators of financial development to analyze the relationship between financial deepening and electricity consumption. Although the comprehensive index has its advantages, some of the information contained in the original index will be omitted. Therefore, this study uses the single index method to measure the financial development of each province by applying financial scale, financial efficiency and financial structure. Among them, the financial scale is measured by the total amount of social financing divided by GDP, expressed by Tofin; financial efficiency is measured by the loan deposit conversion rate expressed by loan divided by deposit, expressed by Finanfi; financial structure is measured by the direct financing amount divided by indirect financing amount, expressed by Finstr; indirect financing method is measured by the bank credit financing divided by GDP, expressed by Load; direct financing method is measured by the securities market financing amount divided by GDP, represented by Stock.

There are many factors that affect electricity consumption, and financial development will also affect electricity consumption through these factors. This study mainly considers economic growth, urbanization 
development and industrial structure optimization. Economic growth is measured by real GDP, which is obtained

353 by dividing the nominal GDP of each province by the GDP deflator index. The GDP delator index is based on 354 1999, which is expressed by Rgdp, and the unit is 10 thousand yuan. The level of urbanization mainly considering population urbanization, which is obtained by the urban population divided by the total population, expressed by Urb. Industrial structure optimization is obtained by the output value of the tertiary industry divided by GDP, and is expressed by Str.

There are many ways to construct spatial weight matrix, and different spatial weight matrix not only relates to the judgment of spatial correlation, but also may affect the robustness of spatial model test and estimation results. This paper constructs 0-1 adjacency spatial weight matrix (W1), geographic distance spatial weight matrix (W2) and economic distance spatial weight matrix (W3) for complementary analysis. The 0-1 adjacency spatial weight matrix $\mathrm{W} 1$ is set according to whether the geographical location is adjacent or not. The regions adjacent to the geographical location are given 1 , and the regions not adjacent to the geographical location are given 0 . The geographical neighboring information of 31 provinces, municipalities and autonomous regions in China can be observed according to the map of the People's Republic of China. The spatial weight matrix W2 of geographical distance is set according to the reciprocal of the spatial distance between the two regions. It is assumed to be the maximum circular distance $D i s_{i j}$ between the capital cities of $i$ province and $j$ province. If $i \neq j$, then

$w_{i j}=1 / D i s_{i j}$; if $i=j$, then $w_{i j}=0$, and the data of $D i s_{i j}$ refer to the results of Yu (2009). The weight of economic distance spatial weight matrix W3 is similar to the geographical specific spatial weight, $w_{i j}=1 /\left|y_{i}-y_{j}\right|, y_{i}, y_{j}$ represents the real GDP of $i$ and $j$ provinces.

\subsection{Data}

The sample area includes 31 provinces, municipalities and autonomous regions in Chinese mainland, with a sample period of 1999-2018. Basic data come from the provincial annual data, wind financial database, China Financial Statistical Yearbook, China Statistical Yearbook, China Energy Statistical yearbook, China Regional Financial Operation Report and the provincial National Economic and Social Development Operation Report and National Bureau of Statistics. The descriptive statistics of each variable is shown in Table 1, and the correlation coefficient is shown in Table 2.

Table 1 Descriptive statistics of variables

\begin{tabular}{cccccc}
\hline Variable & Mean & Std.Dev. & Min. & Max. & Obs \\
\hline Lntoele & 6.6468 & 1.1179 & 1.6094 & 8.7520 & 620 \\
Lntofin & -1.7365 & 0.5496 & -3.8699 & 0.3090 & 620 \\
Lnfineffi & -0.3002 & 0.2107 & -1.4578 & 0.2913 & 620 \\
Lnfinstr & -3.3722 & 1.3596 & -8.1654 & 0.3050 & 620 \\
Lnload & -1.8944 & 0.5330 & -4.3048 & -0.1156 & 620 \\
Lnstock & -5.2666 & 1.3726 & -9.3924 & -1.2927 & 620 \\
Lnrgdp & 7.8326 & 1.0006 & 4.6517 & 9.5579 & 620 \\
Lnurb & -0.7619 & 0.3305 & -1.6660 & -0.1098 & 620 \\
Lnstr & -0.8870 & 0.1853 & -1.2518 & -0.2110 & 620 \\
\hline
\end{tabular}


Table 2 Correlation matrix

\begin{tabular}{cccccccccc}
\hline & Lntoele & Lntofin & Lnload & Lnfineffi & Lnfinstr & Lnstock & Lnrgdp & Lnurb & Lnstr \\
\hline Lntoele & 1.0000 & & & & & & & & \\
Lntofin & 0.1048 & 1.0000 & & & & & & & \\
Lnfineffi & 0.1407 & -0.1286 & 1.0000 & & & & & & \\
Lnfinstr & -0.1102 & -0.0385 & -0.1202 & 1.0000 & & & & \\
Lnload & 0.0752 & 0.9601 & -0.0697 & -0.1717 & 1.0000 & & & \\
Lnstock & -0.0799 & 0.3347 & -0.1461 & 0.9239 & 0.2183 & 1.0000 & & \\
Lnrgdp & 0.8384 & -0.0669 & -0.0179 & 0.0378 & -0.097 & -0.0003 & 1.0000 & & \\
Lnurb & 0.5252 & 0.354 & 0.0260 & -0.0287 & 0.2811 & 0.0807 & 0.4658 & 1.0000 & \\
Lnstr & -0.0323 & 0.4815 & -0.2734 & 0.0672 & 0.3940 & 0.2196 & -0.0496 & 0.4896 & 1.0000 \\
\hline
\end{tabular}

\section{Empirical results and discussions}

\subsection{Cross-sectional dependence test}

The results of cross-sectional dependence (CD) test with LM1, LM2, LM3 and CD statistics are shown in

Table 3. LM1, LM2, $\operatorname{lm} 3$ and CD statistics of lntoele reject the original hypothesis at the significance level of 1\%,

which means that the total electricity consumption of different provinces is not independent. Similarly, LM1, LM2, $\operatorname{lm} 3$ and CD statistics of the variables Intofin, Infineffi, lnfinstr, lnload, Intostock, lnrgdp lnurb lnstr rejected the original hypothesis at the significance level of $1 \%$, This means that the financial scale, financial efficiency, financing structure, indirect financing, direct financing, real GDP, urbanization and industrial structure optimization of each province are also cross-sectional related.

Table 3 Cross-section dependence test results of variables

\begin{tabular}{ccccc}
\hline Variable & LM1 & LM2 & LM3 & CD \\
\hline Lntoele & $9054.114(0.000)$ & $280.632(0.000)$ & $279.816(0.000)$ & $95.144(0.000)$ \\
Lntofin & $3200.199(0.000)$ & $88.674(0.000)$ & $87.858(0.000)$ & $52.950(0.000)$ \\
Lnfineffi & $3946.391(0.000)$ & $113.143(0.000)$ & $112.327(0.000)$ & $46.877(0.000)$ \\
Lnfinstr & $1999.585(0.000)$ & $49.305(0.000)$ & $48.489(0.000)$ & $41.404(0.000)$ \\
Lnload & $2669.278(0.000)$ & $71.265(0.000)$ & $70.449(0.000)$ & $46.706(0.000)$ \\
Lnstock & $1964.765(0.000)$ & $48.163(0.000)$ & $47.347(0.000)$ & $40.410(0.000)$ \\
Lnrgdp & $8284.948(0.000)$ & $255.410(0.000)$ & $254.594(0.000)$ & $90.725(0.000)$ \\
Lnurb & $7954.273(0.000)$ & $244.566(0.00)$ & $243.751(0.000)$ & $85.556(0.000)$ \\
Lnstr & $4770.828(0.000)$ & $140.177(0.000)$ & $139.361(0.000)$ & $63.219(0.000)$ \\
\hline
\end{tabular}

Note: (1) The value in parenthesis is $p$ value; (2) ${ }^{* * *}$ represents significance at $1 \%$ level.

\subsection{Stationary test of variables}

As the cross-sectional data are not independent, we test the stationary of each variable according to CIPS method, and the results are shown in Table 4. When the test model contains intercept term and trend term, the level value (diff $=0$ ) of Lntoele can't reject the original hypothesis, while when the test model doesn't contain intercept term and trend term, the first-order difference value ( $\mathrm{diff}=1)$ of Lntoele rejects the hypothesis $\mathrm{H}_{0}$, which indicates that Lntoele is a first-order single integer series, i.e. I (1); similarly, the other variables are all first-order single integer sequences. So the 9 variables are non-stationary I (1) series. The unit root test is carried out for the weighted spatial items obtained by multiplying these nine indexes with three different spatial weights (W1, W2, 
dependence of variables is not considered, IPS can be directly used to test the stability of each variable. The

409 results of IPS test in Table 4 present that except for the variables W1lnfinstr, W2Infinstr and W3lnfinstr which 410 use IPS test as stationary variable, the other variables which use CIPS test are also I (1), which may be related to 411 the assumed to be cross-sectional independence of each variable by IPS test.

412

Table 4 Test results of variable stationary

\begin{tabular}{|c|c|c|c|c|c|}
\hline \multirow{2}{*}{ Variable } & \multicolumn{2}{|c|}{ IPS statistics } & \multicolumn{2}{|c|}{ CIPS statistics } & \multirow{2}{*}{ Resluts } \\
\hline & $($ Diff. $=0)$ & (Diff.=1) & $($ Diff. $=0)$ & $($ Diff.=1) & \\
\hline Lntoele & $6.923(1.000)$ & $-7.828(0.000)$ & $-1.259(0.104)$ & $-7.545(0.000)$ & $\mathrm{I}(1)$ \\
\hline Lntofin & $0.921(0.822)$ & $-8.244(0.000)$ & $0.984(0.837)$ & $-3.595(0.000)$ & $\mathrm{I}(1)$ \\
\hline Lnfineffi & $5.0134(1.000)$ & $-10.347(0.000)$ & $-1.119(0.132)$ & $-2.945(0.002)$ & $\mathrm{I}(1)$ \\
\hline Lnfinstr & $-0.527(0.299)$ & $-1.723(0.042)$ & $1.737(0.959)$ & $-2.258(0.012)$ & $\mathrm{I}(1)$ \\
\hline Lnload & $-1.129(0.130)$ & $-9.959(0.000)$ & $-0.050(0.480)$ & $-3.929(0.000)$ & $\mathrm{I}(1)$ \\
\hline Lnstock & $1.457(0.928)$ & $-15.344(0.000)$ & $-0.752(0.226)$ & $-5.611(0.000)$ & $\mathrm{I}(1)$ \\
\hline Lnrgdp & $3.469(1.000)$ & $-4.345(0.000)$ & $-0.395(0.346)$ & $-6.760(0.000)$ & $\mathrm{I}(1)$ \\
\hline Lnurb & $1.006(0.843)$ & $-4.378(0.000)$ & $0.067(0.527)$ & $-1.525(0.064)$ & $\mathrm{I}(1)$ \\
\hline Lnstr & $-0.568(0.285)$ & $-13.729(0.000)$ & $1.336(0.909)$ & $-8.286(0.000)$ & $\mathrm{I}(1)$ \\
\hline W1lntoele & $9.784(1.000)$ & $-2.942(0.002)$ & $-0.358(0.360)$ & $-6.154(0.000)$ & $\mathrm{I}(1)$ \\
\hline W1lntofin & $2.218(0.987)$ & $-7.992(0.000)$ & $-0.207(0.418)$ & $-5.433(0.000)$ & $\mathrm{I}(1)$ \\
\hline W1lnfineffi & $8.800(1.000)$ & $-7.392(0.000)$ & $4.135(1.000)$ & $-1.638(0.051)$ & $\mathrm{I}(1)$ \\
\hline W1lnfinstr & $-2.020(0.022)$ & $-14.456(0.000)$ & $0.032(0.513)$ & $-3.933(0.000)$ & $\mathrm{I}(1)$ \\
\hline W1lnload & $-1.253(0.105)$ & $-7.314(0.000)$ & $-1.174(0.120)$ & $-4.505(0.000)$ & $\mathrm{I}(1)$ \\
\hline W1lnstock & $1.490(0.932)$ & $-13.505(0.000)$ & $0.260(0.602)$ & $-2.441(0.007)$ & $\mathrm{I}(1)$ \\
\hline W1Lnrgdp & $3.228(0.999)$ & $-2.841(0.002)$ & $0.260(0.602)$ & $-2.962(0.002)$ & $\mathrm{I}(1)$ \\
\hline W1lnurb & $2.656(0.996)$ & $-2.375(0.009)$ & 2.804(0.997) & $-3.861(0.000)$ & $\mathrm{I}(1)$ \\
\hline W1lnstr & $1.959(0.975)$ & $-12.844(0.000)$ & 2.194(0.986) & $-8.065(0.000)$ & $\mathrm{I}(1)$ \\
\hline W21ntoele & $6.131(1.000)$ & $-2.936(0.002)$ & $1.393(0.918)$ & $-2.928(0.002)$ & $\mathrm{I}(1)$ \\
\hline W21ntofin & $5.001(1.000)$ & $-18.697(0.000)$ & $0.127(0.551)$ & $-3.594(0.000)$ & $\mathrm{I}(1)$ \\
\hline W2lnfineffi & $10.096(1.000)$ & $-6.542(0.000)$ & $0.964(0.832)$ & $-4.866(0.000)$ & $\mathrm{I}(1)$ \\
\hline W2lnfinstr & $-3.476(0.000)$ & $-17.013(0.000)$ & $-0.719(0.236)$ & $-2.878(0.002)$ & $\mathrm{I}(1)$ \\
\hline W2lnload & $0.501(0.692)$ & $-7.693(0.000)$ & $-0.340(0.367)$ & $-3.202(0.001)$ & $\mathrm{I}(1)$ \\
\hline W2lnstock & $2.823(0.998)$ & $-10.944(0.000)$ & $-1.072(0.142)$ & $-5.281(0.000)$ & $\mathrm{I}(1)$ \\
\hline W2Lnrgdp & $2.999(0.999)$ & $-2.947(0.002)$ & $0.160(0.563)$ & $-5.160(0.000)$ & $\mathrm{I}(1)$ \\
\hline W21nurb & $6.514(1.000)$ & $-2.059(0.020)$ & 7.134(1.000) & $-4.393(0.000)$ & $\mathrm{I}(1)$ \\
\hline W2lnstr & $8.266(1.000)$ & $-2.847(0.002)$ & $-1.217(0.112)$ & $-7.550(0.000)$ & $\mathrm{I}(1)$ \\
\hline W31ntoele & $9.790(1.000)$ & $-2.800(0.003)$ & $-0.864(0.194)$ & $-3.762(0.000)$ & $\mathrm{I}(1)$ \\
\hline W3lntofin & $4.181(1.000)$ & $-6.487(0.000)$ & $1.216(0.888)$ & $-9.123(0.000)$ & $\mathrm{I}(1)$ \\
\hline W3lnfineffi & $10.958(1.000)$ & $-1.422(0.078)$ & $2.224(0.987)$ & $-9.003(0.000)$ & $\mathrm{I}(1)$ \\
\hline W3lnfinstr & $-3.029(0.000)$ & $-3.280(0.001)$ & $-1.281(0.100)$ & $-3.500(0.000)$ & $\mathrm{I}(1)$ \\
\hline W3lnload & $-0.321(0.374)$ & $-5.484(0.000)$ & $0.987(0.838)$ & $-7.553(0.000)$ & $\mathrm{I}(1)$ \\
\hline W31nstock & $2.215(0.987)$ & $-13.269(0.000)$ & $-0.858(0.195)$ & $-4.248(0.000)$ & $\mathrm{I}(1)$ \\
\hline W3Lnrgdp & $3.348(0.999)$ & $-7.326(0.000)$ & $-0.730(0.233)$ & $-5.885(0.000)$ & $\mathrm{I}(1)$ \\
\hline W31nurb & $1.857(0.968)$ & $-12.346(0.000)$ & $-0.171(0.432)$ & $-5.875(0.000)$ & $\mathrm{I}(1)$ \\
\hline W31nstr & 4.294(1.000) & $-4.436(0.000)$ & $1.940(0.974)$ & $-2.685(0.004)$ & $\mathrm{I}(1)$ \\
\hline
\end{tabular}


is used to test the stability of the level values ( $\operatorname{diff}=0$ ) of panel series, and if the model only contains trend terms, the critical values of $10 \%, 5 \%$ and $1 \%$ significance levels are $-2.54,-2.62$ and -2.76 ; When using CIPS to test the first-order difference value of panel sequence (diff $=1$ ), if the model does not include the trend item, the critical value under the significance level of $10 \%, 5 \%$ and $1 \%$ is $-2.03,-2.11$ and -2.25 , and the critical value comes from Pesaran (2007); (3) The value in parenthesis is $p$ value.

\subsection{Results of spatial panel co-integration}

\subsubsection{Long-term impact of financial development on electricity consumption}

The maximum likelihood method (MLE) is usually used to estimate the parameters of models with spatial correlation variables (Anselin, 1988; Elhorst, 2014). To make the estimated parameters more comparable, the weighted term model (9) including three types of spatial weights: 0-1 adjacent spatial weight W1, geographical distance spatial weight W2, and economic distance spatial weight W3, adopts MLE method for parameter estimation, and the results are displayed in Table 5. We test the co-integration relationship among these variables based on the residual. Since the estimated results of $\mathrm{M}(1 \mathrm{a})-\mathrm{M}(3 \mathrm{c})$ are obtained based on the cross-sectional dependence hypothesis, LM1, LM2, LM3 and CD tests are used to determine whether there is cross-sectional correlation. Four statistics reject the original hypothesis $\mathrm{H}_{0}$, indicating that the residual $\mu_{i t}$ of those models is still cross-sectional dependence, so CIPS statistics should be used. At 1\% significance level, CIPS statistics reject the null hypothesis $\mathrm{H}_{0}$, which shows that the residual sequence $\mu_{i t}$ is stable. To get more stationary conclusions, this paper also uses IPS method to test the residual of each estimation model, and IPS statistic rejects the null hypothesis $\mathrm{H}_{0}$. According to global co-integration analysis, there are not only local co-integration relationship but also spatial co-integration relationship among electricity consumption, financial development, economic scale, urbanization level and industrial structure optimization in a province.

The estimated parameters $\beta_{1}$ in $\mathrm{M}(1 \mathrm{a}), \mathrm{M}(1 \mathrm{~b})$ and $\mathrm{M}(1 \mathrm{c})$ are between $[0.1839 \sim 0.2445]$, and they all pass the Z-test at the 5\% significance level. The development of financial scale has a significant long-term promoting effect on local electricity consumption; Similarly, the estimated parameters $\beta_{1}$ in $\mathrm{M}(2 \mathrm{a}), \mathrm{M}(2 \mathrm{~b})$ and $\mathrm{M}(2 \mathrm{c})$ are between [1.1253 1.1883], and both pass the Z-test at the significance level of 5\%, so the improvement of financial efficiency has a significant long-term promoting effect on local electricity consumption. As the estimated parameters $\beta_{1}$ in $\mathrm{M}(3 \mathrm{a}), \mathrm{M}(3 \mathrm{~b})$ and $\mathrm{M}(3 \mathrm{c})$ are between [-0.0624 - 0.0587$]$, and also pass the $Z$ test at the significance level of $5 \%$, the financial structure helps to restrain the excessive growth of local electricity consumption in the long term. For other variables, economic development and urbanization are conducive to the growth of local electricity consumption in the long term, while industrial structure optimization is conducive to the suppression of the rapid growth of local electricity consumption.

The parameter estimation of the spatial weighted term reflects the spillover effect, that is, the size of the "neighboring effect". The estimated parameters $\delta_{1}$ of $\mathrm{M}(1 \mathrm{a})-\mathrm{M}(3 \mathrm{c})$ are in the range of $[0.7879 \sim 0.8991]$, and all of them are significantly positive, indicating that the electricity consumption of neighboring provinces will promote the growth of electricity consumption of their own provinces, which may be related to the demonstration, radiation and driving role of the growth of electricity consumption of neighboring regions. For financial scale and financial efficiency, the impact on the local electricity consumption is negative, and the spatial spillover effect of the optimization of the financial structure of the neighborhood will restrain the growth of the local electricity consumption. This is an important discovery that has been ignored in the past research. Because the significance of parameter estimation results will vary with different spatial weights, it is confirmed that different spatial weights have a critical influence on the spatial panel regression results. The economic development of adjacent areas is not conducive to the growth of local electricity consumption in the long term; the urbanization and industrial structure optimization of adjacent areas is conducive to the growth of local electricity consumption. 
Table 5 Estimated results of panel co-integration regression (I)

\begin{tabular}{|c|c|c|c|c|c|c|c|c|c|}
\hline \multirow{3}{*}{ Variable } & \multicolumn{3}{|c|}{ Financial scale } & \multicolumn{3}{|c|}{ Financial efficiency } & \multicolumn{3}{|c|}{ Financial structure } \\
\hline & W1 & W2 & W3 & W1 & W2 & W3 & W1 & W2 & W3 \\
\hline & $\mathrm{M}(1 \mathrm{a})$ & $\mathrm{M}(1 \mathrm{~b})$ & $\mathrm{M}(1 \mathrm{c})$ & $\mathrm{M}(2 \mathrm{a})$ & $M(2 b)$ & $\mathrm{M}(2 \mathrm{c})$ & $\mathrm{M}(3 \mathrm{a})$ & $\mathrm{M}(3 \mathrm{~b})$ & $\mathrm{M}(3 \mathrm{c})$ \\
\hline Cons & $\begin{array}{c}2.2774^{* * *} \\
(5.38)\end{array}$ & $\begin{array}{c}8.8546^{* * * *} \\
(6.38)\end{array}$ & $\begin{array}{c}1.4610^{*} \\
(1.79)\end{array}$ & $\begin{array}{c}2.2754^{* * * *} \\
(5.83)\end{array}$ & $\begin{array}{c}12.2455^{* * * *} \\
(10.19)\end{array}$ & $\begin{array}{c}0.9946 \\
(1.39)\end{array}$ & $\begin{array}{c}2.1659^{* * * *} \\
(5.02)\end{array}$ & $\begin{array}{c}11.1424^{* * * *} \\
(8.20)\end{array}$ & $\begin{array}{l}1.2718 \\
(1.50)\end{array}$ \\
\hline Lntofin & $\begin{array}{c}0.1926^{* * * *} \\
\quad(4.65)\end{array}$ & $\begin{array}{c}0.1839^{* * * *} \\
(4.38)\end{array}$ & $\begin{array}{c}0.2445^{* * * *} \\
(6.32)\end{array}$ & & & & & & \\
\hline Lnfineffi & & & & $\begin{array}{c}1.1253^{* * *} \\
(12.09)\end{array}$ & $\begin{array}{c}1.1883^{* * *} \\
(13.32)\end{array}$ & $\begin{array}{c}1.1488^{* * * *} \\
(12.89)\end{array}$ & & & \\
\hline Lnfinstr & & & & & & & $\begin{array}{c}-0.0587^{* * *} \\
(-4.03)\end{array}$ & $\begin{array}{c}-0.0610^{* * * *} \\
(-4.19)\end{array}$ & $\begin{array}{c}-0.0624^{* * * *} \\
(-4.30)\end{array}$ \\
\hline Lnrgdp & $\begin{array}{c}0.8468^{* * * *} \\
(39.34)\end{array}$ & $\begin{array}{c}0.7933^{* * *} \\
(38.5)\end{array}$ & $\begin{array}{c}0.8088^{* * * *} \\
(38.78)\end{array}$ & $\begin{array}{c}0.8991^{* * * *} \\
(44.48)\end{array}$ & $\begin{array}{c}0.8310^{* * * * *} \\
(44.3)\end{array}$ & $\begin{array}{c}0.8349^{* * * *} \\
(44.35)\end{array}$ & $\begin{array}{c}0.8461^{* * * *} \\
(39.16)\end{array}$ & $\begin{array}{c}0.7879^{* * * *} \\
(38.71)\end{array}$ & $\begin{array}{c}0.7925^{* * * *} \\
(37.94)\end{array}$ \\
\hline Lnurb & $\begin{array}{c}0.4988^{* * *} \\
(6.16)\end{array}$ & $\begin{array}{c}0.5543^{* * *} \\
(7.07)\end{array}$ & $\begin{array}{c}0.3554^{* * *} \\
(4.39)\end{array}$ & $\begin{array}{c}0.1914^{* * *} \\
(2.41)\end{array}$ & $\begin{array}{c}0.2888^{* * * *} \\
(3.93)\end{array}$ & $\begin{array}{r}0.0973 \\
(1.29)\end{array}$ & $\begin{array}{c}0.5621^{\text {**** }} \\
(7.06)\end{array}$ & $\begin{array}{c}0.6358^{* * *} \\
(8.39)\end{array}$ & $\begin{array}{c}0.4116^{\text {**** }} \\
\quad(5.08)\end{array}$ \\
\hline Lnstr & $\begin{array}{c}-1.7682^{* * * *} \\
(-13.98)\end{array}$ & $\begin{array}{c}-1.8884^{* * * *} \\
(-15.32)\end{array}$ & $\begin{array}{c}-1.8324^{* * * *} \\
(-15)\end{array}$ & $\begin{array}{c}-0.7273^{* * *} \\
(-5.57)\end{array}$ & $\begin{array}{c}-0.8706^{* * * *} \\
(-7.03)\end{array}$ & $\begin{array}{c}-0.7001^{* * * *} \\
(-5.80)\end{array}$ & $\begin{array}{c}-1.4917^{* * * *} \\
(-12.23)\end{array}$ & $\begin{array}{c}-1.6343^{* * * *} \\
(-13.73)\end{array}$ & $\begin{array}{c}-1.4654^{* * * *} \\
(-12.44)\end{array}$ \\
\hline $\mathrm{W} *$ Intoele & $\begin{array}{c}0.7293^{* * * *} \\
(12.57)\end{array}$ & $\begin{array}{c}0.6614^{* * * *} \\
(5.62)\end{array}$ & $\begin{array}{c}0.5468^{* * * *} \\
(7.52)\end{array}$ & $\begin{array}{c}0.8242^{* * * *} \\
(16.46)\end{array}$ & $\begin{array}{c}0.6782^{* * * *} \\
(6.48)\end{array}$ & $\begin{array}{c}0.5379^{* * * *} \\
(8.16)\end{array}$ & $\begin{array}{c}0.7558^{* * * *} \\
(13.5)\end{array}$ & $\begin{array}{c}0.7096^{* * * *} \\
(6.15)\end{array}$ & $\begin{array}{c}0.5703^{* * * *} \\
(8.40)\end{array}$ \\
\hline $\mathrm{W}^{*}$ Intofin & $\begin{array}{c}-0.0796 \\
(-1.26)\end{array}$ & $\begin{array}{c}-0.1281 \\
(-1.48)\end{array}$ & $\begin{array}{c}-0.2286^{* * * *} \\
(-2.98)\end{array}$ & & & & & & \\
\hline $\begin{array}{c}W * \text { Infinef } \\
\text { fi }\end{array}$ & & & & $\begin{array}{c}-0.8709^{* * *} \\
(-6.34)\end{array}$ & $\begin{array}{c}-0.8597^{* * * *} \\
(-3.91)\end{array}$ & $\begin{array}{c}-1.5281^{* * * *} \\
(-8.08)\end{array}$ & & & \\
\hline $\mathrm{W}_{\mathrm{r}}^{*}$ Infinst & & & & & & & $\begin{array}{c}0.0288 \\
(1.33)\end{array}$ & $\begin{array}{c}0.0760^{* * * *} \\
(3.14)\end{array}$ & $\begin{array}{c}0.0636^{\text {**** }} \\
(2.72)\end{array}$ \\
\hline $\begin{array}{c}\text { W*Lnrgd } \\
\text { p }\end{array}$ & $\begin{array}{c}-0.8440^{* * * *} \\
(-13.65)\end{array}$ & $\begin{array}{c}-1.4834^{* * * *} \\
(-8.30)\end{array}$ & $\begin{array}{c}-0.5146^{* * * *} \\
(-4.8)\end{array}$ & $\begin{array}{c}-1.0069^{* * * *} \\
(-19.57)\end{array}$ & $\begin{array}{c}-1.9673^{* * *} \\
(-12.9)\end{array}$ & $\begin{array}{c}-0.4546^{* * *} \\
(-5.32)\end{array}$ & $\begin{array}{c}-0.8779^{* * *} \\
(-15.46)\end{array}$ & $\begin{array}{c}-1.8010^{* * * *} \\
(-10.65)\end{array}$ & $\begin{array}{c}-0.4905^{* * *} \\
(-5.34)\end{array}$ \\
\hline $\mathrm{W} * \ln u r b$ & $\begin{array}{c}0.2807^{*} \\
(1.65)\end{array}$ & $\begin{array}{c}1.6055^{* * * *} \\
(3.70)\end{array}$ & $\begin{array}{c}0.9261^{* * * *} \\
(3.80)\end{array}$ & $\begin{array}{c}0.6371^{* * * *} \\
(4.07)\end{array}$ & $\begin{array}{l}2.9004^{* * * *} \\
(7.24)\end{array}$ & $\begin{array}{c}0.6875^{* * *} \\
(3.31)\end{array}$ & $\begin{array}{c}0.2290 \\
(1.36)\end{array}$ & $\begin{array}{c}1.9283^{* * * *} \\
(4.57)\end{array}$ & $\begin{array}{c}0.7044^{* * * *} \\
(3.10)\end{array}$ \\
\hline $\mathrm{W}^{*} \operatorname{lnstr}$ & $\begin{array}{c}1.3822^{* * * *} \\
(6.85)\end{array}$ & $\begin{array}{c}1.2275^{* * * *} \\
(3.87)\end{array}$ & $\begin{array}{c}1.4058^{* * * *} \\
(4.74)\end{array}$ & $\begin{array}{r}0.1697 \\
(0.84)\end{array}$ & $\begin{array}{c}0.6912^{* *} \\
(1.96)\end{array}$ & $\begin{array}{c}1.0513^{* * * *} \\
(3.24)\end{array}$ & $\begin{array}{c}1.1961^{* * * *} \\
(5.95)\end{array}$ & $\begin{array}{c}0.7429^{* *} \\
(2.44)\end{array}$ & $\begin{array}{c}1.2606^{* * * *} \\
(4.35)\end{array}$ \\
\hline $\begin{array}{l}\text { Log } \\
\text { likelihood }\end{array}$ & -336.7239 & -305.0838 & -232.2250 & -280.7434 & -236.3839 & -251.6322 & -339.4545 & -305.5214 & -323.2289 \\
\hline Obs & 620 & 620 & 620 & 620 & 620 & 620 & 620 & 620 & 620 \\
\hline LM1 & $\underset{* *}{9122.019^{*}}$ & $\underset{* *}{9286.428^{*}}$ & $\underset{* *}{9174.563^{*}}$ & $\underset{* *}{8453.064^{*}}$ & $\underset{* *}{8460.735^{*}}$ & $\underset{* *}{8435.270^{*}}$ & $\underset{* *}{8187.635^{*}}$ & $\underset{* *}{8296.306^{*}}$ & $\underset{* *}{8433.476^{*}}$ \\
\hline LM2 & $282.858^{* * * *}$ & $288.250^{* * * *}$ & $284.581^{* * * *}$ & $260.922^{* * * *}$ & $261.174^{* * *}$ & $260.339^{* * * *}$ & $252.219^{* * * *}$ & $255.782^{* * *}$ & $260.280^{* * * *}$ \\
\hline LM3 & $282.043^{* * *}$ & $287.434^{* * * *}$ & $283.766^{* * *}$ & $260.107^{* * * *}$ & $260.358^{* * *}$ & $259.523^{* * *}$ & 251.403 & $254.966^{* * * *}$ & $259.464^{* * *}$ \\
\hline $\begin{array}{c}\mathrm{CD} \\
\text { statistics }\end{array}$ & $95.5066^{* * *}$ & $96.3661^{* * *}$ & $95.7768^{* * *}$ & $91.8116^{* * *}$ & $91.8383^{* * *}$ & $91.6884^{* * *}$ & $90.3067^{* * * *}$ & $90.9590^{* * * *}$ & $91.7602^{\text {**** }}$ \\
\hline $\begin{array}{c}\text { IPS } \\
\text { statistics }\end{array}$ & $-2.3797^{* * * *}$ & $-7.4590^{* * *}$ & $-2.8688^{* * * *}$ & $-1.7093^{* *}$ & $-1.8884^{* *}$ & $-4.1680^{* * * *}$ & $-1.8424^{* *}$ & $-2.9158^{* * *}$ & $-1.7690^{* * *}$ \\
\hline $\begin{array}{c}\text { CIPS } \\
\text { statistics }\end{array}$ & $-4.300^{* * *}$ & $-3.873^{* * * *}$ & $-3.769^{* * * *}$ & $-3.126^{* * *}$ & $-3.203^{* * * *}$ & $-3.271^{* * *}$ & $-4.044^{* * * *}$ & $-3.793^{* * *}$ & $-3.662^{* * * *}$ \\
\hline
\end{tabular}

Note: $(1)^{* * * * * * *}$, indicates the significance level of $10 \%, 5 \%$ and $1 \% ;(2)$ the value in parenthesis is $Z$ statistic.

\subsubsection{Comparison of long-term impact of different financing methods on electricity consumption}

To further compare the long-term impact of indirect financing from bank and direct financing from stock market on electricity consumption, we take Lnload and Lnstock as alternative indicators of financial development, and re-estimate the model (9) with MLE method. The results are shown in Table 6. First, the cross-sectional dependence test for the residual items are conducted, and four statistics reject the original hypothesis $\mathrm{H}_{0}$. CIPS statistics reject the null hypothesis $\mathrm{H}_{0}$ at the significance level of $1 \%$, implying that the residual series is stationary The unit root test results of the residual items of each regression model based on IPS method are consistent with those of CIPS. According to Table 6, there is a global co-integration relationship among the total electricity consumption and indirect financing from banks, economic growth, urbanization development and the optimization of industrial structure; Similarly, the global co-integration relationship also exists among the electricity consumption and the direct financing from stock market, economic growth, urbanization development and industrial structure optimization. 
the long term; while the role of the direct financing scale of the stock market is inhibitory. For spillover effects, the growth of the electricity consumption of "adjacent" provinces will lead to the electricity consumption of their local provinces through demonstration and radiation in the long term. Different financing methods have significant spatial spillover effect on electricity consumption in the long term. However, the difference is that in the long run, the growth of bank financing scale in neighboring areas is not conducive to the growth of local electricity consumption, while the growth of direct financing in neighboring areas is conducive to the growth of local electricity consumption.

Table 6 Estimated results of panel cointegration regression (II)

\begin{tabular}{|c|c|c|c|c|c|c|}
\hline \multirow{3}{*}{ Variable } & \multicolumn{3}{|c|}{ Indirect financing } & \multicolumn{3}{|c|}{ Direct financing } \\
\hline & W1 & W2 & W3 & W1 & W2 & W3 \\
\hline & $M(4 a)$ & $M(4 b)$ & $\mathrm{M}(4 \mathrm{c})$ & $M(5 a)$ & M5b) & $\mathrm{M}(5 \mathrm{c})$ \\
\hline \multirow{2}{*}{ Cons } & $2.3263^{* * *}$ & $9.1484^{* * *}$ & $0.2410^{* * *}$ & $2.2355^{\text {*** }}$ & $11.3555^{* * *}$ & 1.0940 \\
\hline & $(5.51)$ & $(6.65)$ & $(6.46)$ & $(5.16)$ & $(8.27)$ & $(1.3)$ \\
\hline \multirow{2}{*}{ Lnload } & $0.1790^{* * *}$ & $0.1765^{* * *}$ & $0.8094^{* * *}$ & & & \\
\hline & $(4.48)$ & $(4.4)$ & $(38.78)$ & & & \\
\hline \multirow{2}{*}{ Lnstock } & & & & $-0.0360^{* * * *}$ & $-0.0394^{* *}$ & $-0.0276^{*}$ \\
\hline & & & & $(-2.43)$ & $(-2.64)$ & $(-1.86)$ \\
\hline \multirow{2}{*}{ Lnrgdp } & $0.8487^{* * *}$ & $0.7933^{* * *}$ & $0.3710^{* * *}$ & $0.8403^{* * *}$ & $0.7819^{* * *}$ & $0.7880^{* * * *}$ \\
\hline & (39.3) & $(38.51)$ & $(4.59)$ & $(38.69)$ & $(38.27)$ & $(37.43)$ \\
\hline \multirow{2}{*}{ Lnurb } & $0.5137^{* * *}$ & $0.5655^{* * *}$ & $0.5540^{* * *}$ & $0.5815^{* * *}$ & $0.6577^{* * *}$ & $0.4109^{* * * *}$ \\
\hline & (6.38) & $(7.26)$ & (7.83) & $(7.25)$ & (8.62) & $(5.03)$ \\
\hline \multirow{2}{*}{ Lnstr } & $-1.7059^{* * *}$ & $-1.8356^{* * *}$ & $-1.7703^{* * *}$ & $-1.5032^{* * *}$ & $-1.6407^{* * *}$ & $-1.4905^{* * *}$ \\
\hline & $(-13.87)$ & $(-15.33)$ & $(-14.93)$ & $(-11.99)$ & $(-13.42)$ & $(-12.19)$ \\
\hline \multirow{2}{*}{ W*lntoele } & $0.7325^{* * *}$ & $0.6601^{* * *}$ & $0.2320^{* * *}$ & $0.7647^{* * * *}$ & $0.7097^{* * * *}$ & $0.5536^{* * *}$ \\
\hline & (12.79) & $(5.65)$ & (3.19) & $(13.85)$ & (6.14) & $(8.1)$ \\
\hline \multirow{2}{*}{ W*lnload } & -0.0651 & $-0.1417^{* * *}$ & $-0.5253^{* * *}$ & & & \\
\hline & $(-1.05)$ & $(-1.74)$ & $(-5.00)$ & & & \\
\hline \multirow{2}{*}{$\mathrm{W}^{*} \ln s t o c k$} & & & & 0.0195 & $0.0578^{* *}$ & 0.0305 \\
\hline & & & & $(0.90)$ & $(2.35)$ & (1.28) \\
\hline \multirow{2}{*}{$\mathrm{W}^{*}$ Lnrgdp } & $-0.8501^{* * *}$ & $-1.5190^{* * *}$ & $0.9184^{* * *}$ & $-0.8848^{* * *}$ & $-1.8150^{* * *}$ & $-0.4521^{* * *}$ \\
\hline & $(-13.94)$ & $(-8.54)$ & $(3.84)$ & $(-15.98)$ & $(-10.72)$ & $(-5.06)$ \\
\hline \multirow{2}{*}{$\mathrm{W}^{*} \ln u r b$} & 0.2756 & $1.6954^{* * * *}$ & $1.3605^{* * *}$ & 0.2255 & $1.9182^{* * * *}$ & $0.7063^{* * *}$ \\
\hline & (1.62) & (3.94) & $(4.62)$ & (1.33) & $(4.51)$ & (3.1) \\
\hline \multirow{2}{*}{$\mathrm{W}^{*} \operatorname{lnstr}$} & $1.3299^{* * *}$ & $1.1285^{* * *}$ & $1.5042^{*}$ & $1.2104^{* * * *}$ & $0.7488^{* *}$ & $1.2452^{* * *}$ \\
\hline & (6.67) & (3.6) & (1.84) & $(5.92)$ & $(2.43)$ & (4.24) \\
\hline Log likelihood & -337.3910 & -305.1217 & -311.9465 & -344.7274 & -310.6757 & -330.7349 \\
\hline Obs & 620 & 620 & 620 & 620 & 620 & 620 \\
\hline LM1 & $7968.481^{\text {**** }}$ & $8107.333^{* * *}$ & $8022.234^{* * * *}$ & $7968.481^{* * * *}$ & $8107.333^{* * *}$ & $8022.234^{* * * *}$ \\
\hline LM2 & $245.0323^{* * *}$ & $249.5854^{* * * *}$ & $246.7949^{* * *}$ & $245.0323^{* * *}$ & $249.5854^{* * * *}$ & $246.7949^{* * * *}$ \\
\hline LM3 & $244.2165^{* * *}$ & $248.7697^{* * *}$ & $245.9792^{* * *}$ & $244.2165^{\text {*** }}$ & $248.7697^{* * *}$ & $245.9792^{\text {**** }}$ \\
\hline $\mathrm{CD}$ & $89.0407^{* * *}$ & $89.88648^{* * * *}$ & $89.41276^{* * *}$ & $89.04074^{* * * *}$ & $89.88648^{* * * *}$ & $89.41276^{\text {**** }}$ \\
\hline IPS statistics & $-2.7126^{* * * *}$ & $-2.2150^{* *}$ & $-1.7697^{* *}$ & $-2.7126^{* * *}$ & $-2.2150^{* * *}$ & $-1.7697^{* *}$ \\
\hline CIPS statistics & $-4.280^{* * *}$ & $-3.794^{* * *}$ & $-3.727^{* * *}$ & $-4.015^{* * *}$ & $-3.688^{* * *}$ & $-3.483^{* * *}$ \\
\hline
\end{tabular}

\subsection{Results of spatial panel error model}

\subsubsection{Short-term impact on electricity consumption}

For the variables with global co-integration relationship, the spatial panel error correction model can be further constructed to analyze its short-term correlation mechanism. MLE is used to estimate the error correction model (10) which contains the spatial weight weighting terms. The estimation results based on three different spatial weights are shown in Table 7. The coefficients $\xi_{1}$ of the local error correction terms are all significantly negative, indicating that the local error correction mechanism in the short term is tenable. In a province, when the short-term electricity consumption fluctuations deviate from the long-term equilibrium, the system's ability of rectifying deviation will make the unbalanced state return to the balanced state. Furthermore, the coefficients $\xi_{2}$ of the lag term of spatial error are all significantly positive, which demonstrates that the mechanism of spatial error correction also plays a role. When the short-term fluctuation deviates from the long-term equilibrium, the local adjustment and correction mechanism of local electricity consumption will correct the state deviated from the 
long-term equilibrium, and the error spatial spillover effect of neighboring provinces will also promote the short-term deviation of electricity consumption in the province closer to the equilibrium state.

The significant $\delta_{2}$ except for $\mathrm{M}(7 \mathrm{a})$ and $\mathrm{M}(7 \mathrm{c})$, indicates that there is an alternative relationship between the electricity consumption of the two periods in the short term. The development of financial scale and financial efficiency are conducive to electricity consumption in the short term. The impact of financial structure optimization on electricity consumption in the short term is not statistically significant. Consistent with above conclusions, economic development will expand the demand for electricity and bring pressure to the whole electricity supply system, the urbanization can save electricity energy to a certain extent in the short term, which may be related to the agglomeration effect generated in the short term after the transfer of rural population to cities and towns. The optimization and adjustment of industrial structure has uncertain impact on electricity consumption in the short term, and the final effect depends on the electricity saving capacity and rebound effect of industrial structure.

At last, the effect of "neighboring effect" of different explanatory variables is analyzed. The estimated parameters $\delta_{3}$ are all significantly negative. The estimated parameters $\delta_{3}$ in $\mathrm{M}(6 \mathrm{c}), \mathrm{M}(7 \mathrm{c})$ and $\mathrm{M}(8 \mathrm{c})$ are all significantly positive, which means that in the short term, it is difficult to form a consistent conclusion that the electricity consumption of surrounding areas is competitive or exemplary. $\beta_{4}$ in $\mathrm{M}(6 \mathrm{a}), \mathrm{M}(6 \mathrm{~b})$ and $\mathrm{M}(6 \mathrm{c})$ are positive numbers, but fail to meet the significance $Z$ test. For $\beta_{4}$ in $\mathrm{M}(7 \mathrm{a}), \mathrm{M}(7 \mathrm{~b})$ and $\mathrm{M}(7 \mathrm{c})$, only the estimated parameters $\beta_{4}$ in $\mathrm{M}(7 \mathrm{~b})$ is significantly positive numbers, which proves that the improvement of financial efficiency is conducive to the growth of electricity consumption in the short term; None of the estimated parameters $\beta_{4}$ in $\mathrm{M}(8 \mathrm{a}), \mathrm{M}(8 \mathrm{~b}), \mathrm{M}(8 \mathrm{c})$ meet the significance test, which failed to prove that the financial structure adjustment of adjacent areas has significant statistical significance for local electricity consumption in the short

Table 7 Estimation results of spatial panel error model (I)

\begin{tabular}{|c|c|c|c|c|c|c|c|c|c|}
\hline \multirow[b]{2}{*}{ Variable } & \multicolumn{3}{|c|}{ Financial scale } & \multicolumn{3}{|c|}{ Financial efficiency } & \multicolumn{3}{|c|}{ Financial structure } \\
\hline & $\begin{array}{c}\mathrm{W} 1 \\
\mathrm{M}(6 \mathrm{a})\end{array}$ & $\begin{array}{c}\mathrm{W} 2 \\
\mathrm{M}(6 \mathrm{~b})\end{array}$ & $\begin{array}{c}\text { W3 } \\
M(6 c)\end{array}$ & $\begin{array}{c}\text { W1 } \\
\mathrm{M}(7 \mathrm{a})\end{array}$ & $\begin{array}{c}\text { W2 } \\
\mathrm{M}(7 \mathrm{~b})\end{array}$ & $\begin{array}{c}\mathrm{W} 3 \\
\mathrm{M}(7 \mathrm{c})\end{array}$ & $\begin{array}{c}\text { W1 } \\
\mathrm{M}(8 \mathrm{a})\end{array}$ & $\begin{array}{c}\mathrm{W} 2 \\
\mathrm{M}(8 \mathrm{~b})\end{array}$ & $\begin{array}{c}\mathrm{W} 3 \\
\mathrm{M}(8 \mathrm{c})\end{array}$ \\
\hline Cons & $\begin{array}{c}-1.7034^{* *} \\
* \\
(-4.71)\end{array}$ & $\begin{array}{c}-1.0117^{*} \\
(-1.89)\end{array}$ & $\begin{array}{c}0.3107 \\
(0.66)\end{array}$ & $\begin{array}{c}-1.7650^{* *} \\
* \\
(-4.95)\end{array}$ & $\begin{array}{c}-1.1087^{* * *} \\
(-2.22)\end{array}$ & $\begin{array}{c}-0.0521 \\
(-0.11)\end{array}$ & $\begin{array}{c}-1.7030^{* *} \\
* \\
(-4.54)\end{array}$ & $\begin{array}{c}-1.0004^{*} \\
(-1.93)\end{array}$ & $\begin{array}{c}0.2492 \\
(0.52)\end{array}$ \\
\hline Lagdlntoele & $\begin{array}{c}-0.2352^{* *} \\
(-2.45)\end{array}$ & $\begin{array}{c}-0.6135^{* *} \\
* \\
(-4.39)\end{array}$ & $\begin{array}{c}-0.3339^{\text {*** }} \\
(-2.75)\end{array}$ & $\begin{array}{c}-0.0251 \\
(-0.25)\end{array}$ & $\begin{array}{c}-0.3465^{* * *} \\
(-2.31)\end{array}$ & $\begin{array}{c}-0.1531 \\
(-1.18)\end{array}$ & $\begin{array}{c}-0.2219^{* * *} \\
(-2.29)\end{array}$ & $\begin{array}{c}-0.5091^{* *} \\
* \\
(-3.73)\end{array}$ & $\begin{array}{c}-0.3137^{* * *} \\
(-2.57)\end{array}$ \\
\hline Lagdlntofin & $\begin{array}{c}0.1620^{* * *} \\
(2.23)\end{array}$ & $\begin{array}{c}0.3259^{* * * *} \\
(3.45)\end{array}$ & $\begin{array}{c}0.1551^{*} \\
(1.73)\end{array}$ & & & & & & \\
\hline Lagdlnfineffi & & & & $\begin{array}{c}-0.1751 \\
(-0.89)\end{array}$ & $\begin{array}{c}-0.1181 \\
(-0.41)\end{array}$ & $\begin{array}{c}-0.3284 \\
(-1.42)\end{array}$ & & & \\
\hline Lagdlnfinstr & & & & & & & $\begin{array}{c}-0.0139 \\
(-0.55)\end{array}$ & $\begin{array}{c}0.0016 \\
(0.05)\end{array}$ & $\begin{array}{c}0.0071 \\
(0.23)\end{array}$ \\
\hline LagdLnrgdp & $\begin{array}{c}0.4491^{* * * *} \\
(4.11)\end{array}$ & $\begin{array}{c}0.8698^{* * * *} \\
(5.51)\end{array}$ & $\begin{array}{c}0.3235^{* * *} \\
(2.17)\end{array}$ & $\begin{array}{c}0.2040^{*} \\
(1.74)\end{array}$ & $\begin{array}{c}0.6146^{* * * *} \\
(3.83)\end{array}$ & $\begin{array}{c}0.1663 \\
(1.07)\end{array}$ & $\begin{array}{c}0.4563^{* * * *} \\
(4.11)\end{array}$ & $\begin{array}{c}0.7391^{\text {**** }} \\
(4.84)\end{array}$ & $\begin{array}{c}0.2860^{*} \\
(1.92)\end{array}$ \\
\hline Lagdlnurb & $\begin{array}{c}-0.7911^{\text {*** }} \\
(-4.79)\end{array}$ & $\begin{array}{c}-1.1360^{* *} \\
(-5.20)\end{array}$ & $\begin{array}{c}-0.3269^{*} \\
(-1.67)\end{array}$ & $\begin{array}{c}-0.7881^{\text {** }} \\
(-4.82)\end{array}$ & $\begin{array}{c}-1.0875^{* * *} \\
(-5.28)\end{array}$ & $\begin{array}{c}-0.2524 \\
(-1.29)\end{array}$ & $\begin{array}{c}-0.6693^{* * *} \\
* \\
(-4.14)\end{array}$ & $\begin{array}{c}-0.9584^{* *} \\
* \\
(-4.55)\end{array}$ & $\begin{array}{c}-0.2512 \\
(-1.34)\end{array}$ \\
\hline Lagdlnstr & $\begin{array}{c}-0.5671^{\text {*** }} \\
(-2.32)\end{array}$ & $\begin{array}{c}0.7444^{* *} \\
(2.08)\end{array}$ & $\begin{array}{c}0.0397 \\
(0.13)\end{array}$ & $\begin{array}{c}-0.2726 \\
(-1.16)\end{array}$ & $\begin{array}{c}1.4982^{* * * *} \\
(4.50)\end{array}$ & $\begin{array}{c}0.2982 \\
(1.02)\end{array}$ & $\begin{array}{c}-0.5717^{* * *} \\
(-2.40)\end{array}$ & $\begin{array}{c}1.1093^{* * * *} \\
(3.22)\end{array}$ & $\begin{array}{c}0.2549 \\
(0.90)\end{array}$ \\
\hline Lagw*residual & $\begin{array}{c}-1.2327^{* *} \\
* \\
(-18.89)\end{array}$ & $\begin{array}{c}-0.7255^{* *} \\
(-11.33)\end{array}$ & $\begin{array}{c}-0.5985^{* *} \\
* \\
(-9.65)\end{array}$ & $\begin{array}{c}-1.2574^{* *} \\
(-19.21)\end{array}$ & $\begin{array}{c}-0.7940^{* * *} \\
(-13.14)\end{array}$ & $\begin{array}{c}-0.6546^{* *} \\
* \\
(-11.04)\end{array}$ & $\begin{array}{c}-1.2728^{* *} \\
* \\
(-17.99)\end{array}$ & $\begin{array}{c}-0.7561^{* *} \\
(-11.6)\end{array}$ & $\begin{array}{c}-0.5792^{* *} \\
* \\
(-9.27)\end{array}$ \\
\hline Lagdw*Intoele & $\begin{array}{c}-0.1887 \\
(-0.92)\end{array}$ & $\begin{array}{c}-4.4052^{* *} \\
* \\
(-3.90)\end{array}$ & $\begin{array}{c}0.7769^{* *} \\
(2.50)\end{array}$ & $\begin{array}{c}-0.2275 \\
(-1.07)\end{array}$ & $\begin{array}{c}-4.5487^{* * * *} \\
(-3.87)\end{array}$ & $\begin{array}{c}0.8080^{* *} \\
(2.75)\end{array}$ & $\begin{array}{c}-0.1851 \\
(-0.90)\end{array}$ & $\begin{array}{c}-4.0268^{* *} \\
* \\
(-3.6)\end{array}$ & $\begin{array}{c}0.7412^{* * *} \\
(2.43)\end{array}$ \\
\hline Lagdw*Intofin & $\begin{array}{c}0.1731 \\
(1.18)\end{array}$ & $\begin{array}{l}1.1390 \\
(1.24)\end{array}$ & $\begin{array}{c}0.1893 \\
(0.59)\end{array}$ & & & & & & \\
\hline Lagdw*Infineffi & & & & $\begin{array}{c}-0.2079 \\
(-0.45)\end{array}$ & $\begin{array}{c}5.0467^{* *} \\
(2.18)\end{array}$ & $\begin{array}{c}-0.2534 \\
(-0.26)\end{array}$ & & & \\
\hline Lagdw*Infinstr & & & & & & & 0.0781 & -0.1342 & -0.0525 \\
\hline
\end{tabular}




\begin{tabular}{|c|c|c|c|c|c|c|c|c|c|}
\hline & & & & & & & $(1.34)$ & $(-0.48)$ & $(-0.56)$ \\
\hline Lagdw*Lnrgdp & $\begin{array}{c}-0.2189 \\
(-1.10)\end{array}$ & $\begin{array}{c}7.1150^{* * * *} \\
(7.36)\end{array}$ & $\begin{array}{c}0.1283 \\
(0.30)\end{array}$ & $\begin{array}{c}-0.3893^{*} \\
(-1.83)\end{array}$ & $\begin{array}{c}7.4188^{* * * *} \\
(7.56)\end{array}$ & $\begin{array}{l}0.0239 \\
(0.07)\end{array}$ & $\begin{array}{c}-0.6396^{* * *} \\
(-3.13)\end{array}$ & $\begin{array}{c}6.1889^{* * * *} \\
(6.68)\end{array}$ & $\begin{array}{c}0.0978 \\
(0.27)\end{array}$ \\
\hline Lagdw*lnurb & $\begin{array}{c}1.7857^{* * * *} \\
(5.49)\end{array}$ & $\begin{array}{c}-1.4651 \\
(-0.94)\end{array}$ & $\begin{array}{c}-1.9314^{* * *} \\
(-2.15)\end{array}$ & $\begin{array}{c}2.1492^{* * * *} \\
(6.42)\end{array}$ & $\begin{array}{c}-1.4595 \\
(-0.97)\end{array}$ & $\begin{array}{c}-1.6527^{* * *} \\
(-2.07)\end{array}$ & $\begin{array}{c}1.7500^{* * * *} \\
(5.39)\end{array}$ & $\begin{array}{c}-1.0450 \\
(-0.67)\end{array}$ & $\begin{array}{c}-1.8669^{* *} \\
(-2.29)\end{array}$ \\
\hline Lagdw* $\operatorname{lnstr}$ & $\begin{array}{c}0.7665 \\
(1.49)\end{array}$ & $\begin{array}{l}1.8963 \\
(0.68)\end{array}$ & $\begin{array}{l}1.6022 \\
(1.44)\end{array}$ & $\begin{array}{c}1.3263^{* *} \\
(2.62)\end{array}$ & $\begin{array}{c}10.7178^{* * *} \\
* \\
(4.12)\end{array}$ & $\begin{array}{c}2.2919^{* *} \\
(2.07)\end{array}$ & $\begin{array}{c}1.3342^{* * *} \\
(2.54)\end{array}$ & $\begin{array}{c}5.1186^{* *} \\
(2.34)\end{array}$ & $\begin{array}{l}1.6806 \\
(1.49)\end{array}$ \\
\hline $\begin{array}{c}\text { Lagw }^{*} \mathrm{w}^{*} \text { residua } \\
1\end{array}$ & $\begin{array}{c}1.4602^{* * *} \\
(16.94)\end{array}$ & $\begin{array}{c}0.8751^{* * *} \\
(8.21)\end{array}$ & $\begin{array}{c}0.5709^{* * * *} \\
(6.51)\end{array}$ & $\begin{array}{c}1.4907^{* * * *} \\
(17.07)\end{array}$ & $\begin{array}{c}0.9591^{* * * *} \\
(9.71)\end{array}$ & $\begin{array}{c}0.6839^{* * * *} \\
(7.82)\end{array}$ & $\begin{array}{c}1.4953^{* * *} \\
(15.96)\end{array}$ & $\begin{array}{c}0.9039^{* * * *} \\
(8.62)\end{array}$ & $\begin{array}{c}0.5603^{* * * *} \\
(6.32)\end{array}$ \\
\hline Log likelihood & $\begin{array}{c}-706.790 \\
8\end{array}$ & $\begin{array}{c}-814.593 \\
6\end{array}$ & $\begin{array}{c}-854.284 \\
2\end{array}$ & $\begin{array}{c}-689.838 \\
0\end{array}$ & -788.9114 & $\begin{array}{c}-837.989 \\
6\end{array}$ & $\begin{array}{c}-718.940 \\
9\end{array}$ & $\begin{array}{c}-815.393 \\
8\end{array}$ & $\begin{array}{c}-856.635 \\
5\end{array}$ \\
\hline Obs & 620 & 620 & 620 & 620 & 620 & 620 & 620 & 620 & 620 \\
\hline
\end{tabular}

Note: $(1)^{* * *, * *}$, indicates the significance level of $10 \%, 5 \%$ and $1 \% ;(2)$ the value in parenthesis is $Z$ statistic.

\subsubsection{Comparison of short-term impact of financing methods on electricity consumption}

To further compare the short-term impact of bank intermediary financing and stock market direct financing on electricity consumption, we use Dlnload and Dlnstock as alternative indicators of financial development, to carry out MLE regression for spatial error correction model (10) containing three different spatial weight weighting terms, and the results are shown in Table 8. The coefficients of the local error correction terms $\xi_{1}$ are all significantly negative, showing that the local error correction mechanism in the short term is established. When electricity consumption fluctuation in the short-term deviates from equilibrium in the long-term, the system's own correction ability will restore the unbalanced state to the equilibrium state. Further analysis shows that the coefficients $\xi_{2}$ of spatial error lag are all significantly positive, implying that the spatial error correction mechanism also plays a role. When the short-term fluctuation deviates from the long-term equilibrium, not only the local adjustment and correction mechanism of the local electricity consumption will correct the deviation from the long-term equilibrium, the error space spillover effect of neighboring provinces will also promote the short-term deviation of electricity consumption of the province closer to the equilibrium state.

The parameters $\delta_{2}$ again confirmed that the electricity consumption of the two periods in the short term presents a substitution relationship. The bank's indirect financing is conducive to the growth of electricity consumption in the short term; while the direct financing of the stock market has not a significant impact on electricity consumption in the short term; The estimated parameters $\gamma_{1}^{\mathrm{c}}$ proves that in the short term economic development has a significant impact on electricity consumption; the estimated parameters $\gamma_{2}^{\mathrm{c}}$ indicates that urbanization is conducive to energy conservation in the short term; The estimated parameters $\gamma_{3}^{\mathrm{c}}$ based on geographical distance are all positive above the significance level of 5\%, while the estimated parameters $\gamma_{3}^{\mathrm{c}}$ based on economic distance are positive, but they fail to pass the significance test, which shows that the impact of industrial structure optimization on electricity consumption is uncertain in the short term.

The effect of "neighboring effect" of different explanatory variables is analyzed. The estimated parameters $\delta_{3}$ show the characteristics of positive and negative alternation, which means that in the short term, it is uncertain whether the electricity consumption of surrounding areas and the local electricity consumption are competitive or complementary. Although most of the estimation parameters $\gamma_{1}^{\mathrm{d}}$ and $\gamma_{2}^{\mathrm{d}}$ are significant, their positive and negative characteristics are inconsistent with the different choice of spatial weight, so it is not sure whether the economic growth and urbanization of neighboring provinces have positive or negative spillover effect on the electricity consumption of their local provinces in the short term. Most of the estimated values $\gamma_{3}^{d}$ are 
significantly positive, and most of them have meet the significance test, which shows that in the short term, the optimization of industrial structure in adjacent areas also has a more positive role in promoting local electricity consumption.

Table 8 Estimation results of spatial panel error model (II)

\begin{tabular}{|c|c|c|c|c|c|c|}
\hline \multirow[b]{2}{*}{ Variable } & \multicolumn{3}{|c|}{ Indirect financing } & \multicolumn{3}{|c|}{ Direct financing } \\
\hline & $\begin{array}{c}\text { W1 } \\
\text { M(9a) }\end{array}$ & $\begin{array}{c}\mathrm{W} 2 \\
\mathrm{M}(9 \mathrm{~b})\end{array}$ & $\begin{array}{c}\mathrm{W} 3 \\
\mathrm{M}(9 \mathrm{c})\end{array}$ & $\begin{array}{c}\text { W1 } \\
\text { M(10a) }\end{array}$ & $\begin{array}{c}\text { W2 } \\
\text { M(10b) }\end{array}$ & $\begin{array}{c}\text { W3 } \\
\mathrm{M}(10 \mathrm{c})\end{array}$ \\
\hline Cons & $\begin{array}{c}-1.6581^{* * *} \\
(-4.41)\end{array}$ & $\begin{array}{c}-0.9364^{*} \\
(-1.8)\end{array}$ & $\begin{array}{c}0.2739 \\
(0.58)\end{array}$ & $\begin{array}{c}-1.6956^{* * *} \\
(-4.5)\end{array}$ & $\begin{array}{c}-1.0217^{\text {** }} \\
(-1.96)\end{array}$ & $\begin{array}{c}0.1879 \\
(0.40)\end{array}$ \\
\hline Lagdlntoele & $\begin{array}{c}-0.2576^{* * * *} \\
(-2.62)\end{array}$ & $\begin{array}{c}-0.6363^{* * * *} \\
(-4.55)\end{array}$ & $\begin{array}{c}-0.3464^{* *} \\
(-2.85)\end{array}$ & $\begin{array}{c}-0.2456^{* *} \\
(-2.55)\end{array}$ & $\begin{array}{c}-0.5205^{\text {**** }} \\
(-3.84)\end{array}$ & $\begin{array}{c}-0.3234^{* *} \\
(-2.67)\end{array}$ \\
\hline Lagdlnload & $\begin{array}{c}0.1418^{* * *} \\
(2.01)\end{array}$ & $\begin{array}{c}0.3098^{* * * *} \\
(3.33)\end{array}$ & $\begin{array}{c}0.1298 \\
(1.54)\end{array}$ & & & \\
\hline Lagdlnstock & & & & $\begin{array}{c}0.0071 \\
(0.28)\end{array}$ & $\begin{array}{c}0.0449 \\
(1.31)\end{array}$ & $\begin{array}{c}0.0261 \\
(0.84)\end{array}$ \\
\hline LagdLnrgdp & $\begin{array}{c}0.4808^{* * *} \\
(4.27)\end{array}$ & $\begin{array}{c}0.8996^{* * *} \\
(5.67)\end{array}$ & $\begin{array}{c}0.3467^{* * *} \\
(2.33)\end{array}$ & $\begin{array}{c}0.4673^{* * * *} \\
(4.23)\end{array}$ & $\begin{array}{c}0.7470^{* * * *} \\
(4.92)\end{array}$ & $\begin{array}{c}0.2920^{* * *} \\
(1.97)\end{array}$ \\
\hline Lagdlnurb & $\begin{array}{c}-0.7010^{* * *} \\
(-4.20)\end{array}$ & $\begin{array}{c}-1.1034^{* * * *} \\
(-5.12)\end{array}$ & $\begin{array}{c}-0.3336^{*} \\
(-1.72)\end{array}$ & $\begin{array}{c}-0.6508^{* * * *} \\
(-4.01)\end{array}$ & $\begin{array}{c}-0.9744^{\text {**** }} \\
(-4.6)\end{array}$ & $\begin{array}{c}-0.2552 \\
(-1.36)\end{array}$ \\
\hline Lagdlnstr & $\begin{array}{c}-0.7321^{* * *} \\
(-2.98)\end{array}$ & $\begin{array}{c}0.7782^{* *} \\
(2.2)\end{array}$ & $\begin{array}{c}0.0967 \\
(0.33)\end{array}$ & $\begin{array}{c}-0.5955^{* *} \\
(-2.44)\end{array}$ & $\begin{array}{c}1.0107^{\text {**** }} \\
(2.87)\end{array}$ & $\begin{array}{c}0.1965 \\
(0.67)\end{array}$ \\
\hline Lagw*residual & $\begin{array}{c}-1.2511^{* * * *} \\
(-18.03)\end{array}$ & $\begin{array}{c}-0.7491^{* * *} \\
(-11.63)\end{array}$ & $\begin{array}{c}-0.6132^{* * *} \\
(-9.86)\end{array}$ & $\begin{array}{c}-1.2442^{* * *} \\
(-17.70)\end{array}$ & $\begin{array}{c}-0.7391^{* * * *} \\
(-11.35)\end{array}$ & $\begin{array}{c}-0.5704^{* * * *} \\
(-9.14)\end{array}$ \\
\hline Lagdw*Intoele & $\begin{array}{c}0.1044 \\
(0.49)\end{array}$ & $\begin{array}{c}-4.4592^{* * * *} \\
(3.96)\end{array}$ & $\begin{array}{c}0.6848^{* *} \\
(2.22)\end{array}$ & $\begin{array}{c}0.1294 \\
(0.63)\end{array}$ & $\begin{array}{c}-4.1094^{* * * *} \\
(-3.66)\end{array}$ & $\begin{array}{c}0.7485^{* * * *} \\
(2.43)\end{array}$ \\
\hline Lagdw*lnload & $\begin{array}{c}-0.0571 \\
(-0.38)\end{array}$ & $\begin{array}{l}1.0109 \\
(1.15)\end{array}$ & $\begin{array}{c}0.1236 \\
(0.44)\end{array}$ & & & \\
\hline Lagdw*lnstock & & & & $\begin{array}{c}0.0316 \\
(0.56)\end{array}$ & $\begin{array}{c}-0.0175 \\
(-0.06)\end{array}$ & $\begin{array}{c}-0.0595 \\
(-0.59)\end{array}$ \\
\hline Lagdw*Lnrgdp & $\begin{array}{c}-0.5546^{* *} \\
(-2.62)\end{array}$ & $\begin{array}{c}7.0432^{* * *} \\
(7.25)\end{array}$ & $\begin{array}{c}0.1969 \\
(0.48)\end{array}$ & $\begin{array}{c}-0.5629^{* *} \\
(-2.77)\end{array}$ & $\begin{array}{c}6.3448^{* * * *} \\
(6.86)\end{array}$ & $\begin{array}{c}0.1052 \\
(0.28)\end{array}$ \\
\hline Lagdw*lnurb & $\begin{array}{c}1.8687^{* * *} \\
(5.69)\end{array}$ & $\begin{array}{c}-1.0244 \\
(-0.66)\end{array}$ & $\begin{array}{c}-1.9424^{* *} \\
(-2.22)\end{array}$ & $\begin{array}{c}1.8013^{* * * *} \\
(5.53)\end{array}$ & $\begin{array}{r}-1.1117 \\
(-0.72)\end{array}$ & $\begin{array}{c}-1.8758^{* * *} \\
(-2.29)\end{array}$ \\
\hline Lagdw* $\operatorname{lnstr}$ & $\begin{array}{c}1.3650^{* *} \\
(2.58)\end{array}$ & $\begin{array}{c}2.5985 \\
(1.04)\end{array}$ & $\begin{array}{c}1.9700^{*} \\
(1.78)\end{array}$ & $\begin{array}{c}1.2243^{* *} \\
(2.27)\end{array}$ & $\begin{array}{c}4.7967^{* *} \\
(2.04)\end{array}$ & $\begin{array}{l}1.7102 \\
(1.51)\end{array}$ \\
\hline Lagw $^{*}{ }^{*} *$ residual & $\begin{array}{c}1.4687^{* * *} \\
(15.88)\end{array}$ & $\begin{array}{c}0.8882^{* * *} \\
(8.48)\end{array}$ & $\begin{array}{c}0.5909^{* * *} \\
(6.76)\end{array}$ & $\begin{array}{c}1.4677^{* * * *} \\
(15.74)\end{array}$ & $\begin{array}{c}0.8901^{\text {**** }} \\
(8.45)\end{array}$ & $\begin{array}{c}0.5602^{* * * *} \\
(6.35)\end{array}$ \\
\hline Log likelihood & -718.5855 & -812.7608 & -852.4291 & -722.2913 & -816.6934 & -857.6119 \\
\hline Obs & 620 & 620 & 620 & 620 & 620 & 620 \\
\hline
\end{tabular}

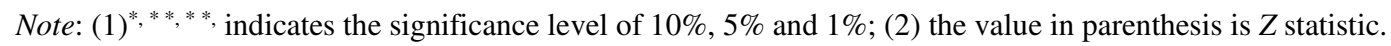

\subsection{Further discussion: Influencing mechanism analysis}

\subsubsection{Path analysis of financial development on electricity consumption}

The mediation effect model is introduced to analyze the influencing mechanism, and results are shown in

Table 9. The first step is to estimate the model (11), and the financial scale is used as the explanatory variable.

565 The coefficient $\psi_{1}$ of M (11a) is 0.2131 , and it has passed the significance $Z$ test. The second step is to estimate

566 the model (12), which is based on the mediation variable named economic growth, urbanization and the industrial structure optimization were taken as the explained variables. Results indicate that the development of financial

568 scale contributes to the growth of electricity consumption through the way of economic scale, urbanization and

569 the optimization of industrial structure. The third step directly uses Sobel method to determine the significance of

570 indirect effect $\phi_{1} \varphi_{2}$, and results all pass the test. For the forth step, the direct effect is significant. In a word, 
according to the mediation effect test, the financial scale promotes the electricity consumption through the way of economic growth and urbanization instead of the way of industrial structure optimization.

Similarly, according to the test steps for mediation effect, it is tested whether financial efficiency promotes electricity consumption through the intermediary channels of economic growth, urbanization and industrial structure optimization. Results in Table 9 indicate that the path of financial efficiency through economic growth, urbanization and industrial structure optimization is not smooth. While for financial structure, the path of economic growth and industrial structure optimization of financial structure are conducive to the inhibition of electricity consumption, while the role of urbanization is not smooth.

Table 9 Estimation results of mediation effect model (I)

\begin{tabular}{|c|c|c|c|c|c|c|c|}
\hline $\begin{array}{c}\text { Financial } \\
\text { scale }\end{array}$ & $\begin{array}{l}\text { Lntoele } \\
\mathrm{M}(11 \mathrm{a})\end{array}$ & $\begin{array}{l}\text { Lnrgdp } \\
\text { M(12a) }\end{array}$ & $\begin{array}{c}\text { Lnurb } \\
\mathrm{M}(13 \mathrm{a})\end{array}$ & $\begin{array}{l}\text { Lnstr } \\
\mathrm{M}(14 \mathrm{a})\end{array}$ & $\mathrm{M}(\underline{15} \underline{\mathrm{a}})$ & $\begin{array}{l}\text { Lntoele } \\
\mathrm{M}(16 \underline{a})\end{array}$ & $\mathrm{M}(17 \underline{\mathrm{a}})$ \\
\hline Cons & $\begin{array}{c}7.0169^{* * * *} \\
(47.34)\end{array}$ & $\begin{array}{c}9.4156^{* * *} \\
(56.47)\end{array}$ & $\begin{array}{c}-0.3922^{* * *} \\
(-9.52)\end{array}$ & $\begin{array}{c}-0.6051^{* * * *} \\
(-27.95)\end{array}$ & $\begin{array}{c}-0.5838^{* * *} \\
(-3.79)\end{array}$ & $\begin{array}{c}7.7572^{* * * *} \\
(57.37)\end{array}$ & $\begin{array}{c}6.6235^{* * * *} \\
(29.81)\end{array}$ \\
\hline Lntofin & $\begin{array}{c}0.2131^{* * * *} \\
(2.62)\end{array}$ & $\begin{array}{c}0.3190^{* * * *} \\
(3.41)\end{array}$ & $\begin{array}{c}0.2129^{* * * *} \\
(9.41)\end{array}$ & $\begin{array}{c}0.1623^{* * *} \\
(13.66)\end{array}$ & $\begin{array}{c}-0.0444 \\
(-1.29)\end{array}$ & $\begin{array}{c}-0.1887^{* *} \\
(-2.54)\end{array}$ & $\begin{array}{c}0.3187^{* * * *} \\
(3.44)\end{array}$ \\
\hline Lnrgdp & & & & & $\begin{array}{c}0.8072^{* * *} \\
(53.88)\end{array}$ & & \\
\hline Lnurb & & & & & & $\begin{array}{c}1.8874^{* * * *} \\
(15.31)\end{array}$ & \\
\hline Lnstr & & & & & & & $\begin{array}{c}-0.6501^{\text {*** }} \\
(-2.37)\end{array}$ \\
\hline$\phi_{1} \varphi_{2}$ & & & & & $\begin{array}{c}0.2575^{* * *} \\
(3.4093)\end{array}$ & $\begin{array}{c}0.6021^{* * *} \\
(9.2342)\end{array}$ & $\begin{array}{c}-0.2074^{* * * *} \\
(-6.5266)\end{array}$ \\
\hline$\phi_{1} \varphi_{2} / \psi_{1}$ & & & & & 1.2083 & 2.8253 & -0.9732 \\
\hline$\phi_{1} \varphi_{2} / \varphi_{1}$ & & & & & -5.7995 & -3.1907 & -0.6507 \\
\hline $\mathrm{R}^{2}$ & 0.0110 & 0.0193 & 0.1253 & 0.2318 & 0.8266 & 0.2833 & 0.0199 \\
\hline Obs & 620 & 620 & 620 & 620 & 620 & 620 & 620 \\
\hline Financial & Lntoele & Lnrgdp & Lnurb & Lnstr & & Lntoele & \\
\hline efficiency & $\mathrm{M}(\underline{11 \mathrm{~b}})$ & $\mathrm{M}(12 \mathrm{~b})$ & $\mathrm{M}(13 \mathrm{~b})$ & $\mathrm{M}(14 \mathrm{~b})$ & $\mathrm{M}(\underline{1} \underline{\mathrm{b}})$ & $\mathrm{M}(\underline{16} \underline{\mathrm{b}})$ & $\mathrm{M}(\underline{17 \mathrm{~b}})$ \\
\hline Cons & $\begin{array}{c}6.8709^{* * * *} \\
(88.66)\end{array}$ & $\begin{array}{c}8.7446^{* * *} \\
(99.10)\end{array}$ & $\begin{array}{c}-0.7496^{* * *} \\
(-32.41)\end{array}$ & $\begin{array}{c}-0.9592^{* * *} \\
(-76.86)\end{array}$ & $\begin{array}{c}-0.2656^{* *} \\
(-2.26)\end{array}$ & $\begin{array}{c}8.1942^{* * * *} \\
(75.66)\end{array}$ & $\begin{array}{c}6.9093^{* * * *} \\
(27.42)\end{array}$ \\
\hline Lnfineffi & $\begin{array}{c}0.7466^{* * *} \\
(3.53)\end{array}$ & $\begin{array}{c}-0.3896 \\
(-1.62)\end{array}$ & $\begin{array}{c}0.0408 \\
(0.65)\end{array}$ & $\begin{array}{c}-0.2405^{* * *} \\
(-7.07)\end{array}$ & $\begin{array}{c}1.0645^{* * * *} \\
(13.60)\end{array}$ & $\begin{array}{c}0.6745^{\text {**** }} \\
(3.75)\end{array}$ & $\begin{array}{c}0.7562^{* * * *} \\
(3.44)\end{array}$ \\
\hline Lnrgdp & & & & & $\begin{array}{c}0.8161^{* * *} \\
(62.49)\end{array}$ & & \\
\hline Lnurb & & & & & & $\begin{array}{c}1.7652^{* * *} \\
(15.40)\end{array}$ & \\
\hline Lnstr & & & & & & & $\begin{array}{c}0.0400 \\
(0.16)\end{array}$ \\
\hline$\phi_{1} \varphi_{2}$ & & & & & $\begin{array}{c}-0.3180 \\
(-0.6200)\end{array}$ & $\begin{array}{c}0.0720 \\
(0.6500)\end{array}$ & $\begin{array}{c}-0.0096 \\
(-0.6624)\end{array}$ \\
\hline$\phi_{1} \varphi_{2} / \psi_{1}$ & & & & & -0.4259 & 0.0965 & -0.0129 \\
\hline$\phi_{1} \varphi_{2} / \varphi_{1}$ & & & & & -0.2987 & 0.1068 & -0.0127 \\
\hline $\mathrm{R}^{2}$ & 0.0198 & 0.0042 & 0.0007 & 0.0748 & 0.8662 & 0.2919 & 0.0198 \\
\hline Obs & 620 & 620 & 620 & 620 & 620 & 620 & 620 \\
\hline $\begin{array}{l}\text { Financial } \\
\text { structure }\end{array}$ & $\begin{array}{l}\text { Lntoele } \\
M(11 \mathrm{c})\end{array}$ & $\begin{array}{l}\text { Lnrgdp } \\
\text { M(12c) }\end{array}$ & $\begin{array}{l}\text { Lnurb } \\
\text { M(13c) }\end{array}$ & $\begin{array}{c}\text { Lnstr } \\
\mathrm{M}(14 \mathrm{c})\end{array}$ & $\mathrm{M}(15 \mathrm{c})$ & $\begin{array}{l}\text { Lntoele } \\
\text { M(16c) }\end{array}$ & $\mathrm{M}(17 \mathrm{c})$ \\
\hline Cons & $\begin{array}{c}6.3413^{* * *} \\
(53.06)\end{array}$ & $\begin{array}{c}8.6933^{* * * *} \\
(64.09)\end{array}$ & $\begin{array}{c}-0.7854^{* * * *} \\
(-22.10)\end{array}$ & $\begin{array}{c}-0.8561^{* * * *} \\
(-43.05)\end{array}$ & $\begin{array}{c}-0.6276^{* * *} \\
(-4.57)\end{array}$ & $\begin{array}{c}7.7293^{* * * *} \\
(56.76)\end{array}$ & $\begin{array}{c}6.2120^{* * * *} \\
(25.98)\end{array}$ \\
\hline Lnfinstr & $\begin{array}{c}-0.0906^{* * * *} \\
(2.76)\end{array}$ & $\begin{array}{c}-0.0499 \\
(-1.34)\end{array}$ & $\begin{array}{c}-0.0070 \\
(-0.71)\end{array}$ & $\begin{array}{c}0.0092^{*} \\
(1.67)\end{array}$ & $\begin{array}{c}-0.0506^{* * *} \\
(-3.70)\end{array}$ & $\begin{array}{c}-0.0782^{* * *} \\
(-2.79)\end{array}$ & $\begin{array}{c}-0.0892^{* *} \\
(-2.71)\end{array}$ \\
\hline
\end{tabular}




\begin{tabular}{|c|c|c|c|c|c|c|c|}
\hline Lnrgdp & & & & & $\begin{array}{c}0.8016^{* * *} \\
(54.47)\end{array}$ & & \\
\hline Lnurb & & & & & & $\begin{array}{c}1.7672^{* * *} \\
(15.34)\end{array}$ & \\
\hline Lnstr & & & & & & & $\begin{array}{c}-0.1510 \\
(-0.62)\end{array}$ \\
\hline$\phi_{1} \varphi_{2}$ & & & & & $\begin{array}{c}-0.040^{* *} \\
(-1.3400)\end{array}$ & $\begin{array}{c}-0.0124 \\
(-0.7100)\end{array}$ & $\begin{array}{l}-0.0014^{* * *} \\
(-1.6695)\end{array}$ \\
\hline$\phi_{1} \varphi_{2} / \psi_{1}$ & & & & & 0.4415 & 0.1365 & -0.0153 \\
\hline$\phi_{1} \varphi_{2} / \varphi_{1}$ & & & & & 0.7905 & 0.1582 & -0.0156 \\
\hline $\mathrm{R}^{2}$ & 0.0121 & 0.0029 & 0.0008 & 0.0045 & 0.8300 & 0.2848 & 0.0128 \\
\hline Obs & 620 & 620 & 620 & 620 & 620 & 620 & 620 \\
\hline
\end{tabular}

582

583

\subsubsection{Path analysis of different financing methods on electricity consumption}

Next, we examine whether different financing methods affect electricity consumption through intermediary variables of economic growth, urbanization and industrial structure optimization, and the results are shown in Table 10. The first step is to estimate the model (11), take the total electricity consumption as the explanatory variable, and Lnload as the explanatory variable. The estimated coefficient $\psi_{1}$ of $\mathrm{M}(11 \mathrm{~d})$ is 0.1578 , and pass the $Z$ significance test,which confirmed the influence of Lnload on electric electricity consumption. The second step is to estimate the model (12), with intermediary variables of economic growth, urbanization and industrial structure optimization being the explained variables, and Lnload is the explaining variable to regress and obtain $\mathrm{M}(12 \mathrm{~d}), \mathrm{M}(13 \mathrm{~d})$ and $\mathrm{M}(14 \mathrm{~d})$. The coefficients $\phi_{1}$ of Lnload in M(12d), M(13d) and M(14d) are 0.2016, 0.1743 and 0.1370, which shows that the indirect financing of banks contributes to the growth of economic scale, the improvement of urbanization level and the optimization of industrial structure. The estimated coefficients $\varphi_{2}$ of the intermediate variables Lnrgdp, Lnurb and Lnstr in $\mathrm{M}(15 \mathrm{~d}), \mathrm{M}(16 \mathrm{~d})$ and $\mathrm{M}(17 \mathrm{~d})$ are $0.8047,1.8511$ and -0.4425 , which shows that the indirect effect exists. Similarly, we use Sobel method to judge the significance of indirect effect $\phi_{1} \varphi_{2}$. The estimated values in $\mathrm{M}(15 \mathrm{~d}), \mathrm{M}(16 \mathrm{~d})$ and $\mathrm{M}(17 \mathrm{~d})$ are $0.1622,0.3226$ and -0.0606 , and all of which meet the requirements of $Z$ statistical significance. Since $\varphi_{1}$ is not significant in $\mathrm{M}(15 \mathrm{~d})$, which indicates that there exists only mediation effect, while $\varphi_{1}$ is significant in $\mathrm{M}(16 \mathrm{~d})$ and $\mathrm{M}(17 \mathrm{~d})$, indicating that the direct effect is significant. Therefore, the indirect financing of banks promotes the electricity consumption through the way of economic growth and urbanization, while the way of industrial structure optimization restrains the electricity consumption. For the direct financing mode of the stock market, the results show that the direct financing mode of the stock market is not smooth in promoting electricity consumption through economic growth, while the direct financing mode of the stock market is conducive to increase electricity consumption through urbanization development and inhibit the electricity consumption through the optimization of industrial structure.

Table 10 Estimation results of mediation effect model

\begin{tabular}{cccccccc}
\hline \multirow{2}{*}{ Bank } & Lntoele & Lnrgdp & Lnurb & Lnstr & & \multicolumn{2}{c}{ Lntoele } \\
& $\mathrm{M}(11 \mathrm{~d})$ & $\mathrm{M}(12 \mathrm{~d})$ & $\mathrm{M}(13 \mathrm{~d})$ & $\mathrm{M}(14 \mathrm{~d})$ & $\mathrm{M}(\underline{15} \underline{\mathrm{d}})$ & $\mathrm{M}(16 \mathrm{~d})$ & $\mathrm{M}(17 \mathrm{~d})$ \\
\hline \multirow{2}{*}{ Cons } & $6.9456^{* * * *}$ & $9.2435^{* * *}$ & $-0.4317^{* * *}$ & $-0.6275^{* * *}$ & $-.4929^{* * *}$ & $7.7448^{* * *}$ & $6.6680^{* * * *}$ \\
& $(41.95)$ & $(49.46)$ & $(-9.17)$ & $(-24.81)$ & $(-3.20)$ & $(51.59)$ & $(28.55)$ \\
\hline
\end{tabular}




\begin{tabular}{|c|c|c|c|c|c|c|c|}
\hline Lnload & $\begin{array}{c}0.1578^{*} \\
(1.88)\end{array}$ & $\begin{array}{c}0.2016^{* *} \\
(2.12)\end{array}$ & $\begin{array}{c}0.1743^{* * *} \\
(7.28)\end{array}$ & $\begin{array}{c}0.1370^{* * * *} \\
(10.66)\end{array}$ & $\begin{array}{c}-0.0045 \\
(-0.13)\end{array}$ & $\begin{array}{c}-0.1649^{* * *} \\
(-2.21)\end{array}$ & $\begin{array}{c}0.2184^{* *} \\
(2.39)\end{array}$ \\
\hline Lnrgdp & & & & & $\begin{array}{c}0.8047^{* * * *} \\
(53.97)\end{array}$ & & \\
\hline Lnurb & & & & & & $\begin{array}{c}1.8511^{* * * *} \\
(15.39)\end{array}$ & \\
\hline Lnstr & & & & & & & $\begin{array}{c}-0.4425^{*} \\
(-1.68)\end{array}$ \\
\hline$\phi_{1} \varphi_{2}$ & & & & & $\begin{array}{l}0.1622^{* *} \\
(2.1199)\end{array}$ & $\begin{array}{c}0.3226^{* * *} \\
(7.2554)\end{array}$ & $\begin{array}{c}-0.0606^{* * * *} \\
(-8.0452)\end{array}$ \\
\hline$\phi_{1} \varphi_{2} / \psi_{1}$ & & & & & 1.0281 & 2.0447 & -0.3842 \\
\hline$\phi_{1} \varphi_{2} / \varphi_{1}$ & & & & & -36.0506 & -1.9566 & -0.2776 \\
\hline $\begin{array}{c}\mathrm{R}^{2} \\
\text { Obs }\end{array}$ & $\begin{array}{c}0.0057 \\
620\end{array}$ & $\begin{array}{c}0.0094 \\
620\end{array}$ & $\begin{array}{c}0.0790 \\
620\end{array}$ & $\begin{array}{c}0.1552 \\
620\end{array}$ & $\begin{array}{c}0.8262 \\
620\end{array}$ & $\begin{array}{c}0.2815 \\
620\end{array}$ & $\begin{array}{c}0.0102 \\
620\end{array}$ \\
\hline Stock & $\begin{array}{l}\text { Lntoele } \\
\mathrm{M}(11 \mathrm{e})\end{array}$ & $\begin{array}{l}\text { Lnrgdp } \\
\mathrm{M}(12 \mathrm{e})\end{array}$ & $\begin{array}{c}\text { Lnurb } \\
\mathrm{M}(13 \mathrm{e})\end{array}$ & $\begin{array}{c}\text { Lnstr } \\
\mathrm{M}(14 \mathrm{e})\end{array}$ & $\mathrm{M}(15 \underline{\mathrm{e}})$ & $\begin{array}{l}\text { Lntoele } \\
\text { M(16e })\end{array}$ & $\mathrm{M}(17 \mathrm{e})$ \\
\hline Cons & $\begin{array}{c}6.3040^{* * * *} \\
(35.47)\end{array}$ & $\begin{array}{c}8.7638^{* * * *} \\
(43.51)\end{array}$ & $\begin{array}{c}-0.6596^{* * *} \\
(-12.55)\end{array}$ & $\begin{array}{c}-0.7309^{* * * *} \\
(-25.35)\end{array}$ & $\begin{array}{c}-0.7374^{* * * *} \\
(-4.97)\end{array}$ & $\begin{array}{c}7.4977^{* * *} \\
(44.54)\end{array}$ & $\begin{array}{c}6.2355^{* * * *} \\
(24.55)\end{array}$ \\
\hline Lnstock & $\begin{array}{c}-0.0651^{* *} \\
(-1.99)\end{array}$ & $\begin{array}{c}-0.0186 \\
(-0.50)\end{array}$ & $\begin{array}{c}0.0194^{* *} \\
(2.01)\end{array}$ & $\begin{array}{c}0.0296^{* * * *} \\
(5.59)\end{array}$ & $\begin{array}{c}-0.0502^{* * * *} \\
(-3.71)\end{array}$ & $\begin{array}{c}-0.1003^{* * *} \\
(-3.62)\end{array}$ & $\begin{array}{c}-0.0623^{*} \\
(-1.86)\end{array}$ \\
\hline Lnrgdp & & & & & $\begin{array}{c}0.8035^{* * *} \\
(54.67)\end{array}$ & & \\
\hline Lnurb & & & & & & $\begin{array}{c}1.8100^{* * * *} \\
(15.73)\end{array}$ & \\
\hline Lnstr & & & & & & & $\begin{array}{c}-0.0937 \\
(-0.38)\end{array}$ \\
\hline$\phi_{1} \varphi_{2}$ & & & & & $\begin{array}{c}-0.0149 \\
(-0.5000)\end{array}$ & $\begin{array}{l}0.0351^{* *} \\
(2.0100)\end{array}$ & $\begin{array}{c}-0.0028^{* * * *} \\
(-5.1252)\end{array}$ \\
\hline$\phi_{1} \varphi_{2} / \psi_{1}$ & & & & & 0.2296 & -0.5394 & 0.0426 \\
\hline$\phi_{1} \varphi_{2} / \varphi_{1}$ & & & & & 0.2977 & -0.3501 & 0.0445 \\
\hline $\begin{array}{c}\mathrm{R}^{2} \\
\text { Obs }\end{array}$ & $\begin{array}{c}0.0064 \\
620\end{array}$ & $\begin{array}{c}0.0004 \\
620\end{array}$ & $\begin{array}{c}0.0065 \\
620\end{array}$ & $\begin{array}{c}0.0482 \\
620\end{array}$ & $\begin{array}{c}0.8300 \\
620\end{array}$ & $\begin{array}{c}0.2909 \\
620\end{array}$ & $\begin{array}{c}0.0066 \\
620\end{array}$ \\
\hline
\end{tabular}

Note: $(1)^{* * *, * *}$, indicates the significance level of $10 \%, 5 \%$ and $1 \%$; (2) the value in parenthesis is $Z$ statistic.

\section{Conclusions and policy implications}

In this study, the spatial panel econometric method and the panel co-integration modeling theory are

611 integrated. The analysis idea of constructing the global co-integration and the spatial panel error correction model 612 is systematically elaborated, and the cross-provincial panel data is combined. This paper analyzes the relationship 613 among financial development, economic growth, urbanization, industrial structure optimization and electricity 614 consumption in China, and draws the following conclusions:

615 First, considering the cross-sectional dependence of units and the non-stationary characteristics of panel data, 616 there is a global co-integration relationship between China's financial development and total electricity 617 consumption rather than only a local co-integration relationship. When the short-term change of electricity 618 consumption deviates from the equilibrium state, the role of global error correction mechanism will make the 619 system return to the equilibrium state from the time and space dimensions, rather than only from the time 620 dimension. Second, in the long run, financial scale, financial efficiency and indirect financing from bank have a 621 positive and direct impact on electricity consumption and a negative spillover effect, while financial structure and 622 direct financing from stock market have a negative and direct impact on electricity consumption and a positive 
623 spillover effect; in the short run, only financial scale and indirect financing from banks have a positive and direct impact on electricity consumption and financial efficiency has a positive and direct impact on electricity consumption. The direct impact of financial structure and direct financing from stock market on electricity consumption and spillover effect are not sure. Third, in the long run, the impact of economic growth on electricity consumption has both positive direct effect and negative spatial spillovers, the influence of urbanization on electricity consumption has both positive direct effect and positive spatial spillover, and the influence of industrial structure optimization on electricity consumption has negative direct effect and positive spatial spillover. In short-term, economic growth in different provinces has a positive direct effect on electricity consumption, urbanization has a negative direct effect on electricity consumption, and industrial structure optimization has a positive spatial spillover on electricity consumption. Finally, the influencing paths are heterogeneous. The financial scale is conducive to electricity consumption through economic growth and urbanization, and can inhibit electricity consumption through industrial structure optimization; the financial efficiency is not smooth through the intermediary role of economic growth, urbanization and industrial structure optimization; the financial structure is conducive to inhibit electricity consumption through economic growth and industrial structure optimization; The indirect financing of banks can benefit the electric electricity consumption by the way of economic growth and urbanization, and restrain the electric electricity consumption by the way of industrial structure optimization; the direct financing of stock market can promote the electric electricity consumption by the way of urbanization, and restrain the electric electricity consumption by the way of industrial structure optimization.

The policy implication of the above conclusions is that: first, under the new normal of economic development, to balance the contradiction between supply and demand of electricity consumption, it is necessary to coordinate the relationship between financial development, economic growth, urbanization, industrial structure optimization and electricity consumption within and among provinces. When making the relevant policies of electricity supply and demand regulation, we should have a global perspective and pay attention to the cross-regional socio-economic connection. Next, to give full play to the financial support role of electricity consumption, it is necessary to speed up the innovation of electricity financial service, optimize the electricity financial service system, so that a wider range of groups, including enterprises and individuals, especially the electricity production and electricity consumer subject to credit financing constraints, can understand the financial service mode, ultimately obtaining conveniently financial services. Further, it is necessary for developing countries like China to promote economic development. New urbanization is an important engine to promote China's economic and social development. The rapid development of China's economy and urbanization are bound to be accompanied by the rapid growth of electricity energy consumption. In the future, to solve the contradiction between supply and demand of China's electricity, on the one hand, we should guide and adjust the financial development. For example, by supporting the electricity production in provinces with large electricity supply and demand gap, it is supposed to support the production and development of clean electricity energy and the improvement of electricity infrastructure to promote the cross-regional transmission of electricity energy and adjust the surplus and shortage. On the other hand, improving the utilization efficiency of electricity energy also 
needs to make good use of the industrial capital allocation and information disclosure functions of the financial 661 system, such as giving priority to supporting the service industry with less electricity consumption, focusing on supporting the development and utilization of green energy-saving buildings, supporting the development, production and sale of electrical products with high technology content and less electricity consumption. At the same time, the supporting fund should be used for technological transformation of enterprise with high electricity consumption characteristics, and be tightened, limited or stopped to support the production industries with high electricity consumption so as to smooth or restrain the excessive growth of electricity consumption.

There are some limitations in this study. First of all, the robust of the results of co-integration regression is affected by the selection of spatial weights. In addition to the 0-1 adjacency spatial matrix, geographical distance spatial matrix, economic distance spatial weight, there are many methods to construct spatial weight matrix, such as institutional distance, weight matrix, etc. How to select the appropriate spatial weight is an unsolved problem, which can be studied in the future study. Additionally, this paper only considers three influencing paths without taking other intermediary factors, such as foreign trade, technological innovation, into account, which needs to be paid attention to in the follow-up study.

\section{References}

Acaravci A, Erdogan S, Akalin G (2015) Electricity consumption, real income, trade openness and foreign direct investment: the empirical evidence from Turkey. International Journal of Energy Economics and Policy 5(54):1050-1057.

Al-Bajjali S K, Shamayleh A Y (2018) Estimating the determinants of electricity consumption in Jordan. Energy 147:1311-1320.

An H, Xu J, Ma X (2020) Does technological progress and industrial structure reduce electricity consumption? Evidence from spatial and heterogeneity analysis. Structural Change and Economic Dynamics 52:206-220. Anselin, L (1988) Spatial econometrics: methods and models. Dordrecht: Kluwer Academic. Apergis N, Payne J E (2012) The electricity consumption-growth nexus: renewable versus non-renewable electricity in Central America. Energy Sources 7(1-4):423-431.

Asteriou D, Spanos K (2019) The relationship between financial development and economic growth during the recent crisis: Evidence from the EU. Finance Research Letters 28:238-245

Baltagi BH, Feng Q, Kao C (2012) A Lagrange multiplier test for cross sectional dependence in a fixed effects panel data model. Journal of Econometrics 170:164-177.

Baron R M, Kenny D. A (1986) The moderator-mediator variable distinction in social psychological research: Conceptual, strategic, and statistical considerations. Journal of Personality and Social Psychology 51:1173-1182. Beenstock M, Felsenstein D (2010) Spatial error correction and cointegration in nonstationary panel data: regional house prices in Israel. Journal of Geographical Systems 12:189-206. Beenstock M, Felsenstein D (2015) Estimating spatial spillover in housing construction with nonstationary panel data. Journal of Housing Economics 28:42-58.

Beenstock M, Felsenstein D (2019) The econometric analysis of non-stationary spatial panel data. Berlin: Springer.

Bencivenga V R, Smith B.D (1991) Financial intermediation and endogenous growth. The Review of Economic Studies 58(2): 195-209. econometric. Review of Economic Studies 47:239-253. 
Chang S C (2015) Effect of financial developments and income on energy consumption. International Review of Economics \& Finance 35:28-44.

704 Cheng Z, Li L, Liu J (2018) Industrial structure, technical progress and carbon intensity in China's provinces. Renewable \& Sustainable Energy Reviews 81(pt.2):2935-2946.

Christopoulos D K, Tsionas, E G (2004) Financial development and economic growth: evidence from panel unit root and cointegration tests. Journal of Development Economics 73(1): 55-74.

Çoban S, Topcu M (2013) The nexus between financial development and energy consumption in the EU: a dynamic panel data analysis. Energy Economics 39:81-88.

Danish, Saud S, Baloch M A, Lodhi R N (2018) The nexus between energy consumption and financial development: estimating the role of globalization in next-11 countries. Environmental Science and Pollution Research 25:18651-18661.

Dasgupta S, Hong J. H, Laplante B, Mamingi N (2004) Disclosure of environmental violations and stock market in the Republic of Korea. Ecological Economics 58(4): 759-777.

Dong X Y, Hao Y (2018) Would income inequality affect electricity consumption? Evidence from China. Energy 142(1):215-227.

Elhorst J P (2014) Spatial econometrics f'rom cross-sectional data to spatial panels. Berlin: Springer.

Faisal F, Tursoy T, Berk N (2018) Linear and non-linear impact of internet usage and financial deepening on electricity consumption for turkey:empirical evidence from asymmetric causality. Environmental Science and Pollution Research 5:11536-11555.

Farhani S, Solarin S A (2017) Financial development and energy demand in the United States: new evidence from combined cointegration and asymmetric causality tests. Energy 134:1029-1037.

Hamdi H, Sbia R, Shahbaz M (2014) The nexus between electricity consumption and economic growth in Bahrain. Economic Modelling 38:227-237.

Hassan M K, Sanchez B, Yu, J S (2011) Financial development and economic growth: New evidence from panel data. The Quarterly Review of Economics and Finance 51: 88-104.

Hayes A F (2013) Introduction to mediation, moderation, and conditional process analysis: a regression-based approach. New York, NY: The Guilford Press.

Im K, Pesaran H, Shin Y (2003) Testing for unit roots in heterogeneous panels. Journal of Econometrics 115: 53-74.

Islam F, Shahbaz M, Ahmed A U, Alam M M (2013) Financial development and energy consumption nexus in Malaysia: a multivariate time series analysis. Economic Modelling 30:435-441.

Islam F, Shahbaz M, Ahmed A U, Alam M. M (2013) Financial development and energy consumption nexus in Malaysia: A multivariate time series analysis. Economic Modelling 30:435-441.

Kahouli B (2017) The short and long run causality relationship among economic growth, energy consumption and financial development: evidence from South Mediterranean countries (SMCs). Energy Econonics 68:19-30.

Khan S, Jam F A, Shahbaz M, Mamun M A (2018) Electricity consumption, economic growth and trade openness in kazakhstan: Evidence from cointegration and causality. OPEC energy review 42(3):224-243.

King R G, Levine R (1993) Finance and growth: schumpeter might be right. Quarterly Journal of Economics 108(7):717-737.

Kosfeld R, Dreger C (2018) Local and spatial cointegration in the wage curve: a spatial panel analysis for german regions. Review of Regional Research 38:53-75.

Kosfeld R, Dreger C (2019) Towards an east German wage curve: nuts boundaries, labour market regions and unemployment spillovers. Regional Science and Urban Economics 76:115-124. 
Econometrics 108: 1-24.

Levine R (1997) Financial development and economic growth: views and agenda. Journal of Economic Literature 35: 688-726.

Levine R (2005) Finance and growth: theory, evidence and mechanisms. In: Aghion, P. and Durlauf, S., Eds., Handbook of Economic Growth. North Holland, Amsterdam 1(1):865-934,

Lin B, Omoju O E, Okonkwo J U (2016) Factors influencing renewable electricity consumption in China. Renewable and Sustainable Energy Reviews 55:687-696.

Liu X, Sun T, Feng Q, Zhang D (2020) Dynamic nonlinear influence of urbanization on China's electricity consumption: Evidence from dynamic economic growth threshold effect. Energy 196:117187

Ma C (2020) Analysis of the Mechanism of Foreign Trade Affecting Energy Consumption: Based on Chinese City Data. Journal of Service Science and Management 13(1):118-133.

Mahalik M K, Babu M S, Loganathan N, Shahbazde M (2017) Does financial development intensify energy consumption in Saudi Arabia. Renewable and Sustainable Energy Reviews 75:1022-1034. Mankiw N G, Scarth W (2008) Macroeconoics Third Canadian Edition[M]. Worth Publisher, New York.2008. Moon H R, Perron B (2004) Testing for a unit root in panels with dynamic factors. Journal of Econometrics 122: $81-126$.

Nguyen C T, Nguyen D T, Phan D K (2021) Factors affecting urban electricity consumption: A case study in the Bangkok Metropolitan Area using an integrated approach of earth observation data and data analysis. Environmental Science and Pollution Research 28:12056-12066.

Niu S, Jia Y, Wang W, He R, Hu L, liu Y (2013) Electricity consumption and human development level: a comparative analysis based on panel data for 50 countries. International Journal of Electrical Power \& Energy Systems 53:338-347.

Ohlan R. Ohlan R (2018) The relationship between electricity consumption, trade openness and economic growth in India. OPEC Energy Review 42: 331-354.

Osman M, Gachino G, Hoque A (2016) Electricity consumption and economic growth in the GCC countries: Panel data analysis. Energy Policy 98:318-327.

Ouédraogo I M (2010) Electricity consumption and economic growth in Burkina Faso: A cointegration analysis. Energy Economics 32(3):524-531.

Payne J E (2010) A survey of the electricity consumption-growth literature. Applied Energy 87(3):723-731.

Pesaran M H (2004) General diagnostic tests for cross-section dependence in panel[R]. Working Paper, Trinity College, Cambridge.

Pesaran M H (2007) A Simple panel unit root test in the presence of cross section dependence. Journal of Applied Econometrics 22:265-312.

Rafindadi A A, Ozturk I (2016) Effects of financial development, economic growth and trade on electricity

Rana R H, Barua S (2015) Financial development and economic growth: Evidence from a panel study on South Asian countries. Asian Economic \& Financial Review 5(10):1159-1173.

Sadorsky P (2010) The impact of financial development on energy consumption in emerging economies. Energy Policy 38(5):2825-2535.

Sadorsky P (2011) Financial development and energy consumption in Central and Eastern European frontier economics[J]. Energy Policy 39(2):999-1006.

Sadorsky P (2013) Do urbanization and industrialization affect energy intensity in developing countries?. Energy Economics 37:52-59.

Sbia R, Shahbaz M, Ozturk I (2017) Economic growth, financial development, urbanisation and electricity 
from

ARDL

approach for

Pakistans.

MPRA

Paper

No.

30138.

https://ideas.repec.org/p/pra/mprapa/30138.html.

Shahbaz M, Nasreen S, Ling C, Sbia R (2014) Causality between trade openness and energy consumption: What causes what in high, middle and low income countries. Energy Policy 70:126-143.

Shahbaz M, Tang C F, Shabbir M S (2011) Electricity consumption and economic growth nexus in Portugal using cointegration and causality approaches. Energy Policy 39(6):3529-3536.

Sharif A, Ali Raza S, Ozturk I, Afshan S (2019) The dynamic relationship of renewable and nonrenewable energy consumption with carbon emission: A global study with the application of heterogeneous panel estimations. Renewable Energy 133:685-691.

Solarin S A, Shahbaz M (2013) Trivariate causality between economic growth, urbanisation and electricity consumption in Angola: Cointegration and causality analysis. Energy Policy 60:876-884.

Solarin S A, Shahbaz M, Khan H N, Razali R B (2019) Financial development, economic growth and electricity consumption:

$$
\text { new }
$$

evidence from

Malaysia.

Global

Business

Review,

807 22(4):1-22.DOI: $10.1177 / 0972150918816899$.

808 Topcu M, Payne J E (2017). The financial development-energy consumption nexus revisited. Energy Sources Part 809 B Economics Planning \& Policy,12(9): 822-830.

810 Ubani O (2013) Determinants of the dynamics of electricity consumption in Nigeria. OPEC Energy Review $81137(2): 149-161$

812 Usman O, Lortile I B, Ike G N (2020) Enhancing sustainable electricity consumption in a large ecological reserve-based country: the role of democracy, ecological footprint, economic growth, and globalisation in Brazil. Environmental Science and Pollution Research 27:13370-13383.

Wang J, Zhao J, Li H (2018) The electricity consumption and economic growth nexus in China: a bootstrap seemingly unrelated regression estimator approach. Computational Economics 52:1195-1211.

Wolde-Rufael Y (2014) Electricity consumption and economic growth in transition countries: A revisit using bootstrap panel Granger causality analysis. Energy Economics 44:325-330.

819 Yin J, Wang S, Gong L (2018) The effects of factor market distortion and technical innovation on china's 820 electricity consumption. Journal of Cleaner Production 188:195-202.

821 Yoo S H, Kwak S Y (2010) Electricity consumption and economic growth in seven South American countries[J]. 822 Energy Policy 38(1):181-188.

823 Yu Y H (2009) CHINA_SPATDWM: Stata module to provide spatial distance matrices for Chinese provinces and cities. consumption in China. Environmental Science and Pollution Research, DOI: 10.1007/s11356-021-16261-8. from 21 transitional countries. Energy Policy 130:253-262.

830 Zhong X, Jiang H, Zhang C, Shi R (2019) Electricity consumption and economic growth nexus in China: an autoregressive distributed lag approach. Environmental Science and Pollution Research 26(14):14627-14637. 


\section{Author contributions}

835 Jianjun Xu contributed to the conception of the study, conducted the data analysis and wrote the 836 manuscript; Xuejiao Ma reviewed and revised the manuscript; Xiaoqing Xu proofread the paper.

\section{Ethics approval and consent to participate}

838 Not applicable.

\section{Consent for publication}

840 Not applicable.

\section{$841 \quad$ Funding}

842 This work was financially sponsored by National Natural Science Foundation of 843 China(No.71773057), Humanities and Social Sciences Research Youth Foundation Project of the 844 Ministry of Education in China (No.16YJCZH124; No.17YJCZH218; No. 21YJC630046); Key 845 Project of National Statistical Science Research (No. 2021LZ17); the Project of Social Science 846 Research Base in Ningbo city (No. JD5-ZD17); Science and Technology Innovation 2025 Major 847 Project in Ningbo city (No. 2019B10009); Key Project of National Statistical Science Research (No. 848 2021LZ17).

\section{Competing interests}

850 The authors declare no competing interests.

851 Availability of data and materials

852 The datasets used in this study are available from the author on reasonable request. 